\title{
Role of the ubiquitin system in regulating ion transport
}

\author{
Daniela Rotin • Olivier Staub
}

Received: 11 July 2010 /Revised: 4 October 2010 / Accepted: 4 October 2010 / Published online: 23 October 2010

(C) Springer-Verlag 2010

\begin{abstract}
Ion channels and transporters play a critical role in ion and fluid homeostasis and thus in normal animal physiology and pathology. Tight regulation of these transmembrane proteins is therefore essential. In recent years, many studies have focused their attention on the role of the ubiquitin system in regulating ion channels and transporters, initialed by the discoveries of the role of this system in processing of Cystic Fibrosis Transmembrane Regulator (CFTR), and in regulating endocytosis of the epithelial $\mathrm{Na}^{+}$channel $(\mathrm{ENaC})$ by the Nedd4 family of ubiquitin ligases (mainly Nedd4-2). In this review, we discuss the role of the ubiquitin system in ER Associated Degradation (ERAD) of ion channels, and in the regulation of endocytosis and lysosomal sorting of ion channels and transporters, focusing primarily in mammalian cells. We also briefly discuss the role of ubiquitin like molecules (such as SUMO) in such regulation, for which much less is known so far.
\end{abstract}

Keywords Aldosterone - Anion channel - Cation channel Cystic fibrosis transmembrane conductance regulator. Electrophysiology · Epithelial Na channels · Ion channel · Potassium channel $\cdot$ Signal transduction $\cdot$ Sodium channel

\footnotetext{
D. Rotin $(\bowtie)$

Program in Cell Biology, The Hospital for Sick Children and Biochemistry Department, University of Toronto, Toronto, Canada e-mail: drotin@sickkids.ca

\section{O. Staub $(\bowtie)$}

Department of Pharmacology and Toxicology, University of Lausanne,

Lausanne, Switzerland

e-mail: Olivier.staub@unil.ch
}

\section{Introduction}

Ion channels play a major role in regulation of the electric properties of virtually every cell. Because of their capability to allow the passage of more than $10^{6}$ ions per second across a membrane, their activity and expression at the plasma membrane is tightly regulated by a plethora of different cellular mechanisms. In recent years it has become evident that the ubiquitin system plays a major role in this control [3]. The modification of target proteins with ubiquitin often (although not always) targets them for degradation by the proteasome or lysosomes [67, 177], and is now recognized as a critical mechanism for regulation of many cellular functions. Ubiquitin is a 76 amino acid long polypeptide, which becomes conjugated via an isopeptide bond on the $\varepsilon$ amino groups of lysine. This is achieved by an enzymatic cascade, involving an E1 (ubiquitin-activating) enzyme, an E2 (ubiquitinconjugating) enzyme, and an E3 ubiquitin-protein ligase. E3 enzymes provide the specificity to the cascade, as they recognize the relevant target proteins and promote the conjugation of ubiquitin. The process is reversible and involves the activity of deubiquitylating (DUB) enzymes. The two major E3 classes known are RING E3s that facilitate transfer of ubiquitin from an E2 to substrates, and Hect E3s, which directly bind ubiquitin and transfer it onto the substrate. In mammals, there are over 1000 E3 enzymes and over 100 DUBs. Different types of ubiquitin modifications can be generated: Ubiquitin can be conjugated as a mono-ubiquitin on a lysine residue. However, frequently poly-ubiquitin chains are generated that link ubiquitins via internal lysines present in ubiquitin. Indeed, it is now known that polyubiquitin chains are formed that can involve any of the lysines on ubiquitin (K6, K11, K27, K29, K33, K48, K63) [218, 223] and hence largely increase 
the amount and versatility of ubiquitylation. Moreover, a number of ubiquitin-like (UBL) proteins have been discovered that modify proteins. Similar, but not identical enzymatic cascades are involved in UBL's conjugation, with the final outcome often not resulting in protein degradation. In this review we summarize the role of the ubiquitin system and UBLs in the regulation of ion channels and transporters both during their processing and their endocytosis and sorting (Table 1).

\section{Role of the ubiquitin system in regulating ion channels in ER/Golgi}

The ERAD system

Proteins destined for the secretory pathway and plasma membrane proteins are inserted co-translationally into the endoplasmic reticulum (ER) membrane, representing approximately one third of all newly synthesized proteins [141]. In the ER, these proteins are subject to regulation by the quality control system, ensuring that proteins fold properly or multimeric complexes assemble correctly. Proteins that do not, are recognized, retrotranslocated into the cytosol, ubiquitylated and degraded by the proteasome, a process known as ER associated degradation (ERAD). As is evident, the nature of the many client proteins is very diverse (soluble proteins, mono- or polytopic membrane proteins, protein complexes), and consequently the machinery is complex. Misfolded or unassembled proteins are recognized by chaperones [143], chaperone-like lectins [29], or protein disulfide isomerase homologues [201]. They assist with folding the client proteins and release them either for ER export or for ERAD (if folding/assembly fails). Proteins are then transferred to secondary quality control machinery, which includes the ubiquitin-protein

Table 1 Ion channels and transporters regulated by the ubiquitin system

\begin{tabular}{|c|c|c|c|}
\hline Transport protein & $\begin{array}{l}\text { Cellular function } \\
\text { of ubiquitylation }\end{array}$ & $\begin{array}{l}\text { Involved enzymes and proteins of the ubiquitin } \\
\text { pathway }\end{array}$ & References \\
\hline $\mathrm{ENaC}$ & ERAD & Doa10, Hrd1p & {$[26]$} \\
\hline CFTR/DF508-CFTR & ERAD/Endocytosis & RMA1, CHIP, gp78, SCF ${ }^{\mathrm{Fbs}}$ & {$[137,139,146,229]$} \\
\hline $\mathrm{ENaC}$ & Endocytosis, recycling & $\begin{array}{l}\text { Nedd4-2, UBE2E3, Usp2, Usp10, } \\
\text { UCH-L3 }\end{array}$ & {$[2,23,27,42,54,99,191]$} \\
\hline $\begin{array}{l}\text { NavS, Nav1.2, Nav1.3, Nav1.5, } \\
\text { Nav1.7, Nav1.8 }\end{array}$ & Endocytosis & Nedd4-2, Nedd4/Nedd4-like proteins & {$[61,170,204]$} \\
\hline KCNQ1/KCNE1 & Endocytosis & Nedd4-2 & {$[95]$} \\
\hline $\mathrm{KCNQ} 2 / 3, \mathrm{KCNQ} 3 / 5$ & Endocytosis & Nedd4-2 & {$[50,175]$} \\
\hline KCNA3/KCNA5 & Endocytosis & Nedd4-2 & {$[17,79]$} \\
\hline CACNB1 & Endocytosis & Nedd4-2 & {$[155]$} \\
\hline TRPV4, TRPC4 & Endocytosis & AIP4/Itch & [213] \\
\hline TRPV6 & Endocytosis & Nedd4-2 & [232] \\
\hline $\mathrm{ClC} 5$ & Endocytosis & WWP2, Nedd4-2 & {$[84,176]$} \\
\hline $\mathrm{ClC} 2$ & Endocytosis & Nedd4-2 & {$[150]$} \\
\hline $\mathrm{ClC}-\mathrm{Ka} / \mathrm{Barttin}$ & Endocytosis & Nedd4-2 & {$[51]$} \\
\hline TTHY2 & Endocytosis & Nedd4-2 & {$[77]$} \\
\hline EAAT2 & Endocytosis & Nedd4-2 & {$[17]$} \\
\hline DMT1 & Endocytosis & Nedd4-2/Ndfip1 & {$[59,83]$} \\
\hline ASIC & Endocytosis & Parkin/Pick1 & [96] \\
\hline AQP2 & Endocytosis & $?$ & [98] \\
\hline $\mathrm{PC} 1, \mathrm{PC} 2$ & Sorting to lysosome & $?$ & {$[85]$} \\
\hline PC2 & Degradation by proteasome & $\mathrm{SCF}^{\beta-\operatorname{Trcp}}$ & [198] \\
\hline ROMK1 & Endocytosis & $\mathrm{POSH}$ & {$[123]$} \\
\hline Gap1 & Endocytosis & Rsp5/Bul1 or Bul2 & [189] \\
\hline Smf1, Smf2 & Endocytosis & Bsd2 & {$[124]$} \\
\hline Connexin 43 & Endocytosis & Nedd4-2 & {$[115]$} \\
\hline TRPM4 & Endocytosis & SUMO & [110] \\
\hline $\mathrm{K} 2 \mathrm{P} 1$ & Intrinsic activity & SUMO & {$[161]$} \\
\hline $\mathrm{K}_{\mathrm{v}} 2.1$ & Intrinsic activity & SUMO & {$[40]$} \\
\hline $\mathrm{K}_{\mathrm{v}} 1.5$ & Intrinsic activity & SUMO & [11] \\
\hline
\end{tabular}


ligases Hrd1 [107] and its homologue gp78 [35]. Hrd3 and SEL1L associate with Hrd1 and contribute to ERAD substrate processing [121, 140]. Derlin-1, -2 and -3 , possibly with Sec61, have been suggested to form the retrotranslocation channel in the ER membrane, and the p97-Ufd1-Np14 complex assists with "retrotranslocating" and delivering the proteins to the proteasome $[121,145$, $160,227,228]$. Ubiquitylation may take place during or after retrotranslocation. A number of additional ubiquitinprotein ligases can participate in ERAD, including Doa10 [196], RMA1 [139], CHIP (in combination with Hsp70) [137] or $\mathrm{SCF}^{\mathrm{fbs}}$ ligases [229].

\section{ERAD of transmembrane proteins}

The quality control of transmembrane proteins in the ER is a challenging task, as these proteins have three topologically distinct regions that have to be monitored to ensure that the folding of the protein is correct: extracellular, transmembrane and intracellular domains. Consequently, it has been proposed that there are three different types of ERAD mechanisms with respect to transmembrane proteins [33, 196, 206]. ERAD-C (cytoplasmic pathways) monitors and recognizes the cytoplasmic regions of the protein (as is the case for the Cystic Fibrosis Transmembrane Regulator (CFTR) channel, where the cytoplasmic Hsp70/CHIP act; see below), whereas the ERAD-L system detects luminal folding defects (with the help of Bip, calnexin/calyculin, OS-9, XTP3-B and others). Alternatively membrane proteins and especially multimeric transmembrane protein complexes may have folding defects in the membranespanning region, qualifying these as ERAD-M class of molecules. These pathways have been primarily characterized in yeast [33], where different ERAD complexes with different E3 ubiquitin-protein ligases play a role. It is currently believed that at least in yeast, ERAD-C substrates require Doa10, whereas ERAD-L and ERAD-M substrates require the Hrd1p ubiquitin-protein ligase. In mammalian cells it is likely that other ligases are involved as well. It is possible that depending on the nature of the protein several of these mechanisms are implicated in parallel, as seems to be the case for CFTR (see below). There is evidence for a large number of multimeric transmembrane complexes and channels whose assembly is controlled by ER and which involve ERAD. Examples include the T-cell receptor [19, 226], the nicotinic acetylcholine receptor [38, 207], $\mathrm{GABA}_{\mathrm{A}}$ receptors [71], voltage-gated $\mathrm{Na}^{+}$channels [174], connexin 32 [205], NMDA receptors [104, 190], $\mathrm{K}^{+}$channels [65, 132, 133, 179, 199, 224, 231], $\mathrm{Ca}^{2+}$-channels [209], Inositol 1,4,5-triphosphate receptors [211, 219] and $\mathrm{ENaC}[103,202]$. The mechanisms by which these proteins are recognized by ERAD vary widely, including intramembrane charges [19], C-terminal PDZ binding motifs
[190, 199], or positive charges in the cytoplasmic domains [231]. It is becoming clear that these events can be regulated. This is the case for KCNK3 channels, in which 14-3-3 binding to phosphorylation sites can overcome the ER retention by dibasic signals [144], the IP3 receptors which become degraded upon stimulation, an event that involves the ERAD protein SPFH2 [154], or Kv1.2 Kchannel in which phosphorylation plays a role in ER exit [224]. Here, we discuss two selected examples, namely the quality control and ERAD of CFTR, which is one of the best characterized transmembrane ERAD substrate, and $\mathrm{ENaC}$, which is an example of a multimeric transmembrane protein assembled in the ER (Fig. 1).

CFTR as a model for integral membrane proteins subjected to ERAD

The cystic fibrosis transmembrane regulator (CFTR) is the gene product responsible for cystic fibrosis (CF) when mutated [167]. The large interest into ERAD of this multimembrane spanning protein is due to a mutant CFTR (CFTR $\Delta$ F508), which is present approximately in $90 \%$ of
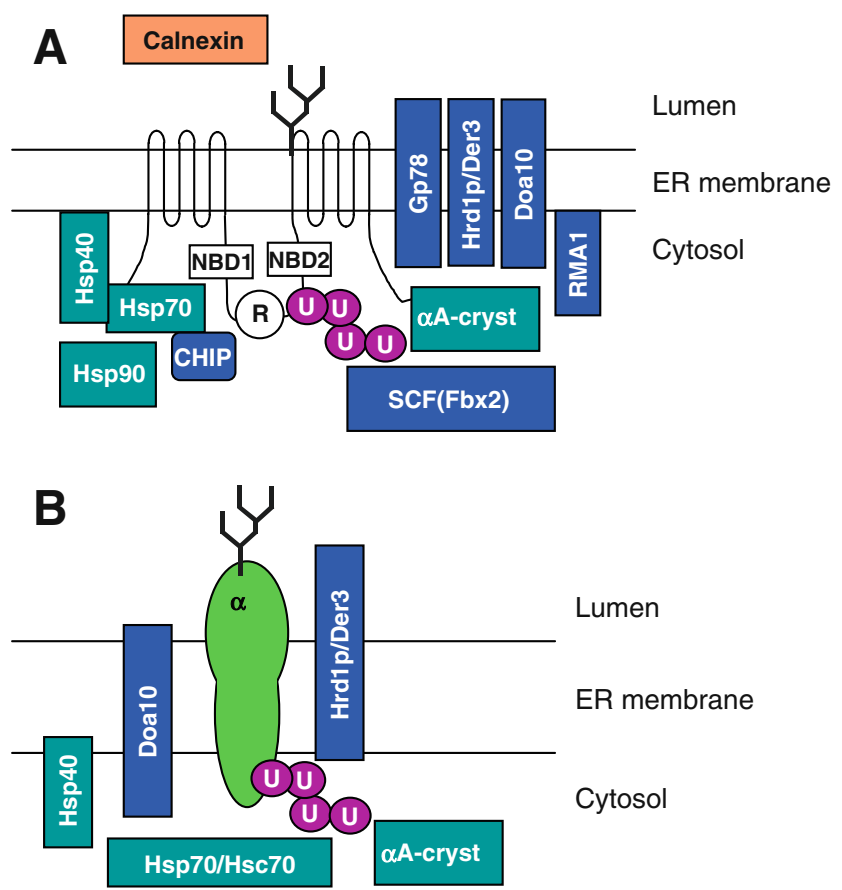

Fig. 1 Chaperones and ubiquitin-protein ligases involved in ERAD of CFTR and ENaC. a ER associated degradation of CFTR. On the cytosolic side, Hsp40, Hsp70 and Hsp90, as well as $\alpha$ A-crystallin (cryst), are involved in recognition of the unfolded cytosolic regions, whereas calnexin is involved in luminal control. Hsp70 recruits the ubiquitin-protein ligase CHIP. Other ubiquitin-protein ligases are also involved, such as Gp78, Hrd1p/Der3, Doa10, as well as the cytosolic RMA1 and SCF(Fbx). b The ERAD machinery for the 2-TM domain $\mathrm{ENaC}$ subunits is less well characterized, and possibly less complex. The heatshock proteins Hsp70/Hsc70, Hsp40 and $\alpha$ A-crystallin have been shown to play a role, as well as Doa10 and Hrd1p/Der3 
all Caucasian CF patients, and which represents a folding mutant that is retained in the ER and degraded by ERAD [109]. Indeed, it was one of the first ERAD substrates to be shown to be degraded in a ubiquitin-dependant fashion by the proteasome $[93,210]$. CFTR is a member of the ATP binding cassette $(\mathrm{ABC})$ transporter superfamily and contains 1,480 amino acids. It is composed of two membrane spanning domains (with six transmembrane (TM) each), two cytosolic nucleotide binding domains (NBD1 and NBD2), and a regulatory $\mathrm{R}$ region. The assembly of this protein into a functional ion channel is complex, as the different domains have to be folded in a coordinated fashion, whereby they are thought to interact in a co- and post-translational fashion. The complexity of this process is illustrated by the fact that only $25 \%$ of the wild-type channel are properly folded and exported to the cell surface, whereas the rest is degraded via ERAD; in the case of CFTR $\triangle$ F508 the entire pool is degraded by ER [37]. As with other proteins chaperones (Hsp40, Hsp70, Hsp90, $\alpha$ A-crystallin, calnexin) $[5,233]$ contribute to the recognition of CFTR by ERAD, as do lectins [147]. ERAD involves the participation of various complexes, such as Derlin-1, either to retain CFTR in the ER membrane or to serve as retrotranslocon, and promoting the interaction with the ubiquitin-protein ligase RMA1 that acts in concert with the E2 enzyme Ubc6e [139]. It is believed that RMA1 is capable of recognizing folding defects in CFTR in a co-translational fashion, whereas CHIP, another E3 ligase, appears to interact together with Hsp70 in a post-translational manner with misfolded NBD2 [137]. Other ubiquitin-protein ligases are also important, such as gp78 [139], or $\mathrm{SCF}^{\mathrm{Fbs}}$ [229]. As well, the extracting activity of $\mathrm{p} 97 / \mathrm{Ufd} 1 / \mathrm{Np} 14$ is necessary for CFTR degradation [68].

$\mathrm{ENaC}$, an example of a multimeric protein controlled by ERAD

The amiloride-sensitive epithelial $\mathrm{Na}^{+}$channel $(\mathrm{ENaC})$ is composed of three subunits, $\alpha \beta \gamma$, and is expressed primarily in the apical membrane of salt-absorbing epithelia, such as those in the distal nephron, distal colon and lung [47], where it participates it salt and fluid absorption (see below). It is well established that efficient functional expression of this channel at the cell surface requires all three subunits $[28,57,87,135,136] . \alpha \beta$ and $\alpha \gamma$ dimers are also able to generate small amiloridesensitive currents, whereas $\beta \gamma$ channels are rather weakly expressed at the cell surface [20]. Study of such "dimeric" channels is important for both physiological and pathophysiological reasons. $\mathrm{ENaC}$ is highly regulated by the steroid hormone aldosterone, which positively regulates this channel. At least in the kidney, this is achieved by regulating the expression level of $\alpha \mathrm{ENaC}$; without aldosterone stimulation $\alpha \mathrm{ENaC}$ is expressed at only very low levels; under such conditions the $\beta$ and $\gamma$ subunits are retained in an as yet undefined compartment [126, 134]. Aldosterone stimulation leads to $\alpha \mathrm{ENaC}$ expression, assembly with the $\beta \gamma$ subunits and translocation of the channel to the plasma membrane [126]. It is not understood how and where the $\beta \gamma$ dimmers are retained, and how they are protected from degradation. Moreover, there is a pathological condition, pseudohypoaldosteronism type $\mathrm{I}$, in which mutations in the genes encoding either $\alpha-, \beta-$ or $\gamma \mathrm{ENaC}$ lead to inactivation of these subunits, leaving the cell with only two subunits [34]. As for many other multimeric membrane complexes it is believed that the $\mathrm{ENaC}$ channel subunits assemble in the ER and are exported to the plasma membrane, and that at least part of the unassembled subunits are retained in the ER and eventually degraded by ERAD. It is not clear how subunits assemble but they do so early in biosynthesis, possibly prior to glycosylation. It was shown earlier that the $\mathrm{N}$-terminus of $\gamma \mathrm{ENaC}$ plays a crucial role in channel assembly [4], that each subunit can interact with each other to form dimers, and that multiple $\mathrm{ENaC}$ domains participate in its assembly [25]. Processing/assembly of $\mathrm{ENaC}$ is inefficient, with less than $1 \%$ of synthesized subunits reaching the plasma membrane [202, 214], suggesting that the bulk of newly synthesized proteins are eliminated by ERAD. Little is known how unassembled $\mathrm{ENaC}$ chains are retained in the ER, and how they are targeted for ERAD. No ER retention signal has been identified, but a $\mathrm{C}$-terminal exit signal was characterized recently [103]. Beside the fact that $\mathrm{ENaC}$ needs to assemble all three subunits in order to be efficiently targeted to the cell surface, the evidence (sometimes indirect) for ERAD of ENaC subunits is as follows: (1) Intracellular $\mathrm{ENaC}$ subunits are polyubiquitylated [13, 23, 54, 90, 130, 171, 192, 234], whereas $\mathrm{ENaC}$ at the cell surface appears to be either mono- or multi-monoubiquitylated [171, 216]. (2) Proteasome, but not lysosomal inhibition, interferes with turnover of individually expressed $\mathrm{ENaC}$ subunits in MDCK cells, whereas the turnover of $\mathrm{ENaC}$ subunits in cells expressing all three subunits is inhibited by both inhibitors. This implies that there are 2 populations of $\mathrm{ENaC}$ subunits in such cells, assembled ones (multi-mono-ubiquitylated) that traffic to the plasma membrane and later to the lysosomes, and the unassembled ones (polyubiquitylated) that are degraded by ERAD and the proteasome [192]. (3) It has been shown that proteasome inhibition can increase $\mathrm{ENaC}$ activity in A6 cells, most likely by inhibiting ERAD of ENaC subunits, and increasing the level of unassembled subunits, consequently increasing the chance of channel assembly in the ER [129]. Recently, some light has been 
shed on the machinery that appears to be involved in ERAD. First, it has been shown that Hsp70, a stressinduced protein, and Hsc70 (a constitutively expressed Hsp70 paralogue), both cytosolic chaperone involved in ER quality control, play an important role in $\mathrm{ENaC}$ regulation [69]. Interestingly, when co-expressed in Xenopus laevis oocytes, Hsp70 stimulates cell surface expression of $\mathrm{ENaC}$, whereas $\mathrm{Hsc} 70$ decreases it. This difference is not very well understood, but it suggests that Hsc70 targets ENaC for ERAD, whereas Hsp70 may promote its folding. The same group also identified $\alpha \mathrm{A}$ crystallin as a protein involved in ERAD [103]. Similar to what was done for CFTR, $\alpha \mathrm{ENaC}$ was expressed in yeast cells, and its turnover tested in various mutants, including Hsp 26 and Hsp 42 mutants, in which the protein was stabilized. It was then shown that $\alpha \mathrm{A}$-crystallin (the Hsp26 orthologue) reduces $\mathrm{ENaC}$ activity and cell surface expression when co-expressed in Xenopus oocytes. Evidence was provided that it was the delivery pathway to the plasma membrane (i.e. secretory pathway) that was involved and not the endocytic pathway. Recently, the expression of $\mathrm{ENaC}$ subunits in yeast cells has led to additional characterization of the ERAD mechanisms involved in $\mathrm{ENaC}$ degradation [26]. It was shown that singly expressed $\mathrm{ENaC}$ subunits display several defects in different compartments (cytosolic, luminal and possibly membrane), as evidenced by the observation that both Doa10 (a ubiquitin-protein ligase important for cytosolic substrates), as well as Hrdlp (luminal and membrane regions) were required for turnover of the $\mathrm{ENaC}$ subunits. Moreover, it was shown that luminal Hsp40 proteins (Jem1 and Scj1), but not Bip (a luminal Hsp70 chaperone), were involved in turnover and ubiquitylation of ENaC. This was further supported in Xenopus oocytes, in which the Hsp40 orthologue ERdj3 and ERdj4 inhibited amiloride-sensitive currents [26]. However, it remains to be seen if these mechanisms are also valid in more physiological cells, such as renal epithelia.

\section{Role of the ubiquitin system in endocytosis, sorting and recycling of ion channels and transporters}

The role of ubiquitin in endocytosis and sorting of transmembrane (TM) proteins has received much attention over the past 15 years, initially from work in yeast $[64,78$, 82] and in mammalian cells [114, 191]. Relevant to this review, our initial observation that $\mathrm{ENaC}$ binds the Nedd4/ Nedd4-2 family of E3 ligases [191] opened the field to many subsequent studies that have focused on the role of ubiquitin system, and in particular the Nedd4 family proteins, in the regulation of cell surface stability and endocytosis of ion channels and transporters in mammals.
Regulation of ENaC by Nedd4-2

Perhaps the best-studied example of the regulation of ion transport by ubiquitin is that of $\mathrm{ENaC}$ regulation by Nedd42. As indicated above, $\mathrm{ENaC}$ regulates salt and fluid absorption in epithelia of several organs, including kidney, lung and colon. The critical role of $\mathrm{ENaC}$ in salt and fluid absorption in these tissues/organs is underscored by the findings that loss or gain of function mutations in this channel in humans causes pseudohypoaldosteronism Type I (PHAI) or pseudoaldosteronism (Liddle syndrome- see below), respectively, diseases that are also recapitulated in mouse models bearing the same mutations $[89,120]$. In the kidney, $\mathrm{ENaC}$ function is up-regulated by the hormone aldosterone, which binds the mineralocorticoid receptor (MR), while in the lung it is up-regulated by glucocorticoids and their cognate receptor (GR) [125]. As indicated above, $\mathrm{ENaC}$ is comprised of 3 subunits, $\alpha \beta \gamma$ [28], with a short proline-rich sequence, called the PY motif (PPxYxxØ, minimal consensus $=\mathrm{L} / \mathrm{PPxY}$ ), present at the cytosolic Cterminus of each subunit $[173,187,191]$. The PY motif of $\beta$ or $\gamma \mathrm{ENaC}$ is deleted or mutated in Liddle syndrome [74, $75,120,183]$, a hereditary hypertension caused by increased activity and number of $\mathrm{ENaC}$ channels at the plasma membrane [57]. These PY motifs serve as binding sites for Nedd4 proteins [191], in particular Nedd4-2 [2, 76, 99, 188]. Nedd4-2 (Nedd4L) possesses a C2 domain that can be spliced out [92], $4 \mathrm{WW}$ domains that bind PY motifs [102, 191], and an E3 ligase Hect domain. The third WW domain, present in all Nedd4-2 but absent in most Nedd4-1 proteins (except human, zebrafish and Drosophila Nedd4-1), appears to provide higher affinity interactions to PY motifs [80, 101], but both WW3 and WW4 of Nedd4-2 are essential for interaction with and regulation of $\mathrm{ENaC}[60,92,100]$. It is curious that human Nedd4-1, which also possesses $4 \mathrm{WW}$ domains including WW3, can only inhibit $\mathrm{ENaC}$ function upon removal of its inhibitory $\mathrm{C} 2$ domain $[100,185]$, in line with a recent demonstration of inhibition of Hect catalytic activity by the $\mathrm{C} 2$ domain of the Nedd 4 family relative Smurf2 [217] and Nedd4-1 and -2 [208], which in the latter can be relieved by elevated $\mathrm{Ca}^{2+}$ levels. However, it should be emphasized that the data with Nedd4-1 have been acquired in heterologous expression systems; to date there is no in vivo evidence that endogenous Nedd4- 1 is involved in $\mathrm{ENaC}$ regulation.

Given the ability of Nedd4-2 to interact with the PY motifs of $\mathrm{ENaC}$, which are deleted/mutated in Liddle syndrome, it was proposed [191] and later demonstrated $[2,99]$ that the increased retention of channels at the plasma membrane in this disease may be caused by impaired ubiquitylation and endocytosis of the mutant channels (Fig. 2a). Indeed, ENaC's cell surface stability was shown earlier to be negatively regulated by ubiquitylation on its $\alpha$ 
Fig. 2 Regulation of $\mathrm{ENaC}$ by Nedd4-2. a Nedd4-2 WW domains binds to the PY motifs ubiquitylation and endocytosis. b Hormones and factors that inhibit the ability of Nedd4-2 to suppress $\mathrm{ENaC}$, including aldosterone, vasopressin, insulin and inflammatory mediators.

These factors promote Nedd4-2mediated phosphorylation via kinases such as Sgk1, Akt, PKA or IKK $\beta$, leading to binding of 14-3-3 proteins to the phosphorylated Nedd4-2 and preventing this E3 ligase from interacting with $\mathrm{ENaC}$.

c Nedd4-2 mediated suppression of $\mathrm{ENaC}$ can be stimulated by metabolic stress that leads to activation of AMPK and enhanced Nedd4-2 interaction with $\mathrm{ENaC}$. $U$ ubiquitin of $\mathrm{ENaC}$, leading to channel

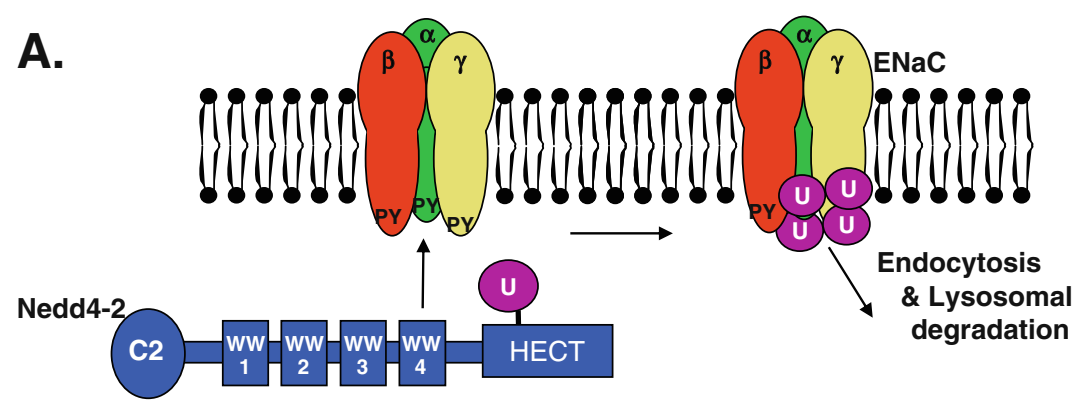

B.
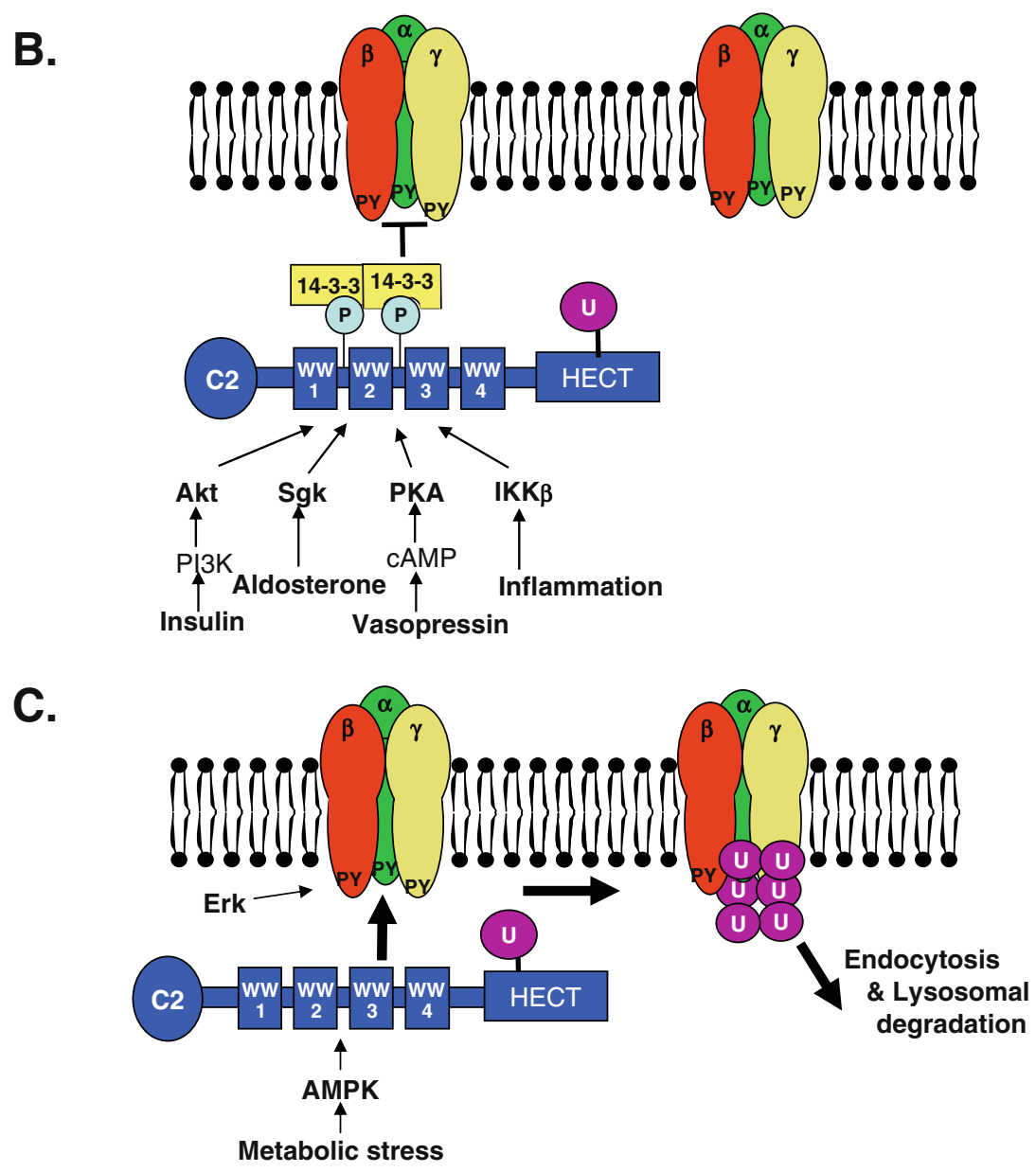

and $\gamma$ subunits [192]. In support, recent studies have demonstrated that Nedd4-2 can ubiquitylate $\mathrm{ENaC}$ at the plasma (apical) membrane [127, 216, 234]. Moreover, the increased retention of the PY motif mutant ENaCs at the plasma membrane is primarily caused by impaired internalization of the mutant channels, with some defects also observed in channel sorting and cAMP-dependent mobilization of channels from a sub-apical pool [127]. The nature of $\mathrm{ENaC}$ ubiquitylation is not entirely clear, but several reports recently suggested that the channel is mono or multi-mono ubiquitylated at the cell at the cell surface [171, $216,234]$, a finding that is in accord with the known role of mono or oligo-ubiquitylation in endocytosis and sorting of transmembrane proteins [81]. Another group proposed that native $\mathrm{ENaC}$ in $\mathrm{A} 6$ cells is regulated by polyubiquitylation and is degraded by the proteasome [129, 130] although it needs to be established whether the polyubiquitylated pool is the one at the plasma membrane. The type of ubiquitin linkage employed is not known, but one would expect to identify at least some K63-linked ubiquitylation of ENaC, a linkage often detected in proteins destined for endosomal sorting and lysosomal degradation, and was described in transmembrane proteins that are target for Rsp5 (the yeast Nedd4 orthologue)—mediated ubiquitylation and endocytosis/sorting [63, 111, 149]. In addition to regulating cell surface stability, the PY motifs (Nedd4-2 binding sites) of 
$\mathrm{ENaC}$ also regulate its response to intracellular $\mathrm{Na}^{+}$ concentrations, since feedback inhibition by $\mathrm{Na}^{+}$exhibited by WT ENaC is inhibited in a PY motif mutant of the channel [45, 106, 151].

The clear prediction from these findings is that the increased retention of active $\mathrm{ENaC}$ at the plasma membrane would increase $\mathrm{Na}^{+}$reabsorption in the kidney, leading to hypertension, as seen in Liddle syndrome patients. Indeed, knock-in mice bearing the Liddle syndrome mutation in $\beta E N a C$ exhibit salt-induced hypertension, metabolic alkalosis and hypokalemia, leading to renal and cardiac hypertrophy which resembles the human Liddle disease [159]. In accord, these Liddle mice exhibit enhanced alveolar fluid clearance following pulmonary edema [162]. Interestingly, recently generated knockout (KO) mice of Nedd4-2 exhibit a similar phenotype, with salt-induced hypertension (which was inhibited by amiloride) and cardiac hypertrophy, suggesting upregulation of $\mathrm{ENaC}$. Indeed, $\mathrm{ENaC}$ protein expression in the kidney of these mice was elevated, and rectal PD measurements indicated excessive $\mathrm{ENaC}$ activity also in their colon [181]. While the potential effect of loss of Nedd4-2 on lung function of these KO mice was not described, a separate study using RNAi to knockdown Nedd4-2 in rat lungs immediately after birth, which led to $\sim 60 \%$ reduction in level of Nedd4-2, has demonstrated increased $\mathrm{ENaC}$ expression along with reduced extravascular lung water following knockdown [116]. This suggests that Nedd4-2 suppresses ENaC function in the lung, similar to its function in the kidney and colon.

It has long been recognized that CFTR regulates $\mathrm{ENaC}$ function, in most cases leading to inhibition of $\mathrm{ENaC}$ activity by reducing its open probability [194]. In cystic fibrosis (CF), where CFTR is defective, $\mathrm{Na}^{+}$and fluid absorption is elevated, leading to dehydration of airway surface fluid, mucus accumulation and repeated bacterial infections $[22,46]$. Recent work by Mall, Boucher and coworkers provided further support for this model, by demonstrating that overexpression of $\mathrm{ENaC}(\beta \mathrm{ENaC})$ in mouse airways leads to a CF-like phenotype, a process that can be ameliorated by treatment of the mice with amiloride $[131,235]$. An important issue that needs to be addressed is, therefore, why do Liddle syndrome patients, exhibiting excessive $\mathrm{ENaC}$ activity, not develop CF-like disease?

The elevated blood pressure (BP) in the Nedd4-2 KO mice suggests that mutations or variation in the NEDD4-2 gene in humans may be involved in the regulation of blood pressure [168]. In support, a recent study suggested that a cryptic splice variant (generated by the SNP rs4149601) that generates Isoform I of Nedd4-2 (NEDD4-2 A allele, aka Nedd4-2C8 [48]) is associated with hypertension in a Chinese group of patients [128]. This splice isoform, which generates an inactive protein [48], was proposed to interact with other Nedd4-2 isoforms and block their function in a dominant negative fashion, thus leading to enhanced $\mathrm{ENaC}$ activity [8]. Another variant, encoding NEDD4-2-P355L, was shown to be less effective at suppressing $\mathrm{ENaC}$ than the native protein, likely due to its enhance phosphorylation [62] (see below).

\section{Role of Nedd4-2 in hormone-mediated regulation of ENaC}

As indicated above, aldosterone and vasopressin (ADH), as well as insulin, enhance $\mathrm{ENaC}$ function. In search for transcripts and proteins that exhibit early response to aldosterone and glucocorticoids, several groups identified serum and glucocorticoid- regulated kinase 1 (Sgk1), a relative of Akt (PKB) [212]; Sgk1 was shown to enhance $\mathrm{ENaC}$ function by stimulating an increase in $\mathrm{ENaC}$ abundance at the plasma membrane in response to aldosterone, including in renal collecting ducts $[7,36$, $126,142,182]$. Subsequent work, initially from Staub and co-workers, demonstrated that Sgk1 phosphorylates Nedd42 on Ser residues (S444, S338), a process that involves a PY motif present in Sgk1 and suggests a Nedd4-2:Sgk1 interaction (most likely of low affinity [80, 163]); This phosphorylation leads to interference with the ability of Nedd4-2 to interact with $\mathrm{ENaC}$, resulting in increased abundance of channels at the plasma membrane, as demonstrated in a Xenopus oocyte model system, tissue culture cells and cortical collecting ducts [41, 58, 186] (Fig. 2b). Unlike Nedd4-2, Nedd4-1 does not possess Sgk phosphorylation sites, and is not known to be regulated by aldosterone. In addition to Sgk1, it appears that cAMPactivated PKA can also phosphorylate Nedd4-2, on the same sites as those used by Sgk1, leading to increased $\mathrm{ENaC}$ abundance due to its inability to interact with phosphorylated Nedd4-2 [184]. Since cAMP is generated and PKA activated in response to vasopressin release and its binding to its V2 receptor, these collective results suggest that Sgk1 and PKA serve as convergent points to phosphorylate Nedd4-2 and block its ability to suppress $\mathrm{ENaC}$ in response to both aldosterone and vasopressin (Fig. 2b), the two major hormones regulating fluid absorption, blood volume and BP.

In addition to the regulation of Sgk/PKA/Nedd4-2 by aldosterone and vasopressin, Insulin was recently shown to increase $\mathrm{ENaC}$ function by activating its downstream effectors Akt1 and Sgk1, thus feeding into the same Nedd4-2 pathway and connecting cellular metabolism and growth to $\mathrm{ENaC}$ [112]. Likewise, Il-1 $\beta$-induced cortisol production was shown to stimulate fluid absorption $(\mathrm{ENaC}$ activation) via Sgk-mediated Nedd4-2 inhibition in fetal guinea pigs lungs [117]. Additionally, the WNK kinase was also shown to activate Sgk1, resulting in suppression of Nedd4-2 and elevated ENaC function [222]; mutations in 
WNK cause PHAII, a form of hypertension. Interestingly, another player, IkappaB kinase $\beta$ (IKKB), was recently shown to phosphorylate Nedd4-2 on S444 (the same site as that phosphorylated by Sgk1), leading to enhanced accumulation and function of $\mathrm{ENaC}$ at the plasma membrane [49]. These latter results provide another arm to the regulation of $\mathrm{ENaC}$ by Nedd4-2, connecting it to inflammation and the immune system (Fig. 2b).

How does phosphorylation of Nedd4-2 by Sgk/PKA prevent it from interacting with $\mathrm{ENaC}$ ? Recent studies identified 14-3-3 proteins as binding partners to phosphorylated Nedd4-2; 14-3-3 maintains phosphorylated Nedd4-2 in a "blocked" form that cannot bind $\mathrm{ENaC}[13,90]$. Recent work also suggested that a heterodimer of the 14-3$3 \beta: 14-3-3 \varepsilon$ is required for this interaction [118] and that these 14-3-3 isoforms are themselves induced by aldosterone [119]. The exact mechanism of this "blockage" is still unknown, since the phosphorylation sites on Nedd4-2 are located outside the WW domains that bind the PY motifs of $\mathrm{ENaC}$; it is possible that a 14-3-3 dimer binds to Nedd4-2 and alters its conformation, thus masking the binding sites on its WW domains. This, however, remains speculative until the structure of Nedd4-2 in complex with the PY motifs of $\mathrm{ENaC}$, in the presence or absence of 14-3-3, is solved.

While the Sgk1/Nedd4-2 pathway can lead to enhanced $\mathrm{ENaC}$ function, it should be kept in mind that aldosterone, vasopressin and Sgk1 can also activate $\mathrm{ENaC}$ independently of Nedd4-2. Evidence for this is provided by the observations that (1) aldosterone and Sgk1 can increase cell surface levels of $\mathrm{ENaC}$ channels bearing the Liddle syndrome mutations (which cannot properly bind Nedd4-2) [7, 9, 43, 182], (2) Cortical collecting tubules harvested from mice bearing the Liddle syndrome mutation reveal normal response to aldosterone [39], (3) ENaC activity in the colon of these Liddle mice is enhanced by aldosterone [12], and (4) ENaC was shown to be inhibited by WNK4 kinase, a process inhibited by Sgk1, which phosphorylates WNK4 [165, 166].

Interestingly, recent reports provide a connection between $\mathrm{ENaC}$ and the metabolic state of the cell, by demonstrating that the metabolic sensor AMP kinase (AMPK) inhibits ENaC function in a PY motif-dependent manner, by enhancing its ability to interact with Nedd4-2, thus reducing cell surface stability of the channel $[6,14,30]$ (Fig. 2c); the latter effect did not involve Sgk or PKA, and overall suggests that under metabolic stress, reducing ENaC function by activated AMPK, leading to enhanced channel endocytosis, would prevent cellular $\mathrm{Na}^{+}$overload. Likewise, Erk (part of the MAPK pathway) downregulates $\mathrm{ENaC}$ by phosphorylating it on $\mathrm{Thr}$ residues in the $\mathrm{C}$ termini of $\beta$ and $\gamma \mathrm{ENaC}$, thus facilitating $\mathrm{ENaC}$ interaction with Nedd4/Nedd4-2 [138, 180, 225], although it is not clear yet how such phosphorylation would increase ENaC: Nedd4/Nedd4-2 binding given the hydrophobic nature of WW domain:PY motif interaction [101, 102].

Two knockout models of Sgk1 have been generated and the role of Sgk1 in $\mathrm{ENaC}$ regulation has been evaluated in these mice. Wulff et al. found that Sgk1 (-/-) mouse displayed a salt-losing phenotype only when mice were kept under low $\mathrm{Na}^{+}$diet. Under such conditions, $\mathrm{ENaC}$ was also weakly expressed, as evidenced by potential difference (PD) measurement in isolated cortical collecting ducts and by immunohistochemistry [221]. Somewhat different data were obtained by Fejes-Toth et al. Although they also found a salt-losing phenotype under low $\mathrm{Na}^{+}$diet, they observed by in situ patch clamping CCD cells that amiloridesensitive $\mathrm{Na}^{+}$currents were upregulated under these conditions, suggesting that other $\mathrm{Na}^{+}$transporters must be upregulated, including the thiazide-sensitive $\mathrm{Na}^{+} / \mathrm{Cl}^{-}$cotransporter [55]. Hence the precise role of Sgk1 in vivo in the kidney remains to be further characterized, and the mechanism of aldosterone regulation continues to remain obscure.

\section{De-ubiquitylating enzymes and $\mathrm{ENaC}$}

The critical role of the E3 ubiquitin ligase Nedd4-2 and ubiquitylation in the regulation of $\mathrm{ENaC}$ endocytosis and cell surface stability prompted a search for de-ubiquitylation enzymes (DUBs) that may participate in this regulation as well. Recently, a DUB induced by aldosterone, Usp-45, was identified by Verrey and colleagues [54]. Usp-45 deubiquitylates $\mathrm{ENaC}$ and stimulates $\mathrm{ENaC}$ cell surface stability and function; this effect is dependent on the presence of the PY motifs of $\mathrm{ENaC}$ and on its prior ubiquitylation by Nedd4-2, but is independent of Sgk1 [54]. Another DUB that was described to regulate $\mathrm{ENaC}$ is the endosomal DUB, UCH-L3 [27]. UCH-L3 increases cell surface expression of $\mathrm{ENaC}$ by de-ubiquitylating it, presumably in an endosomal compartment, and enhancing its recycling to the plasma membrane. Given the known role of cAMP in inducing $\mathrm{ENaC}$ recycling [127], it would be interesting to test whether UCH-L3 participates in this process. In addition, the DUB Usp10 was recently identified as a transcript/protein whose expression is elevated following vasopressin stimulation, an increase that leads to enhanced $\mathrm{ENaC}$ abundance and function at the plasma membrane [23]. Usp-10 utilizes an adapter protein, SNX3, to carry out its effect on $\mathrm{ENaC}$, as detailed below.

Thus, specific DUBs appear to oppose the action of Nedd4-2 (directly, or indirectly via an adapter protein), leading to increased $\mathrm{ENaC}$ stabilization at the plasma membrane (Fig. 3), especially in response to hormones that are released into the blood stream to promote $\mathrm{ENaC}$ function and $\mathrm{Na}^{+}$/fluid absorption. 


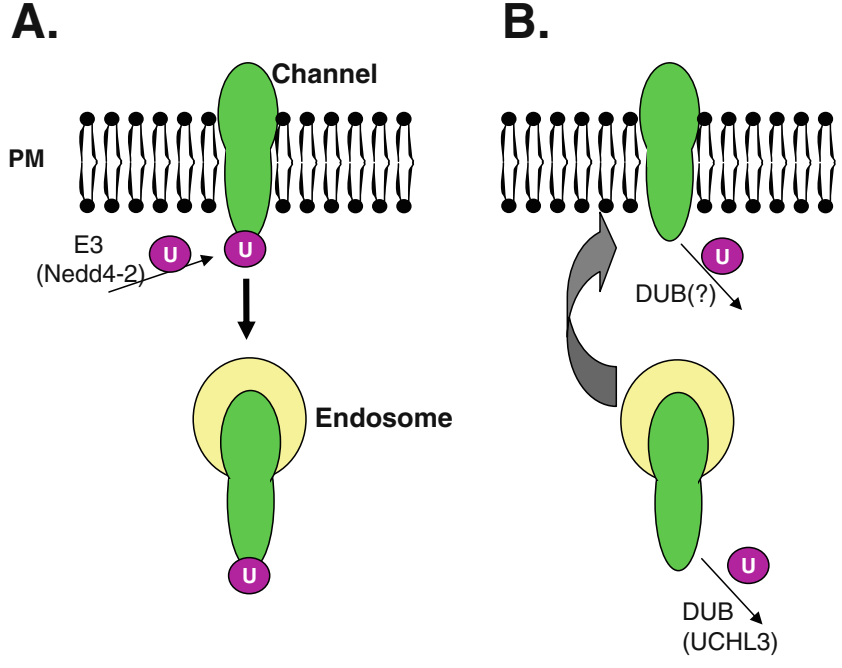

Fig. 3 Opposing actions of E3 ligases and DUBs on channel abundance at the cell surface. a Ubiquitin ligases such as Nedd4-2 ubiquitylate ion channels (e.g., $\mathrm{ENaC}$ ) at the plasma membrane, leading to its endocytosis. This action can be opposed (b) by deubiquitylating enzymes (DUBs), such as USP2-45 or UCH-L3, which remove ubiquitins from the channel, thus increasing its cell surface abundance by promoting recycling (e.g., bin the case of UCH-L3) or possibly by decreasing endocytosis. $U$ ubiquitin

\section{Relationship between regulation of ENaC ubiquitylation and its proteolytic cleavage}

Proteolytic cleavage of the ectodomain of $\mathrm{ENaC}$ by serine proteases leads to activation of the channel by increasing its open probability $(\mathrm{Po})[88,169,203]$. In particular, the $\alpha$ and $\gamma$ subunits are the targets for such cleavage: $\alpha \mathrm{ENaC}$ is cleaved by Furin at two site, releasing an inhibitory peptide/ tract, whereas $\gamma \mathrm{ENaC}$ is cleaved by Furin at one site and by anther protease, such as prostasin/CAP1, elastase or plasmin, at a second site, to promote release of the inhibitory tract $[24,31,32,86,153]$. It appears that the inhibitory tract provide higher affinity for $\mathrm{Na}^{+}$[178] and may mediate the well-known self-inhibition of $\mathrm{ENaC}$ by extracellular(luminal) $\mathrm{Na}^{+}$[151]; thus, removal of the inhibitory tract by proteases promotes channel activation (increased Po) by decreasing sensitivity to luminal $\mathrm{Na}^{+}$ [178]. Curiously, while proteases increase $\mathrm{ENaC} \mathrm{Po}$, their effect is connected to ubiquitylation, Nedd4-2 and Usp-45. Work from Snyder and colleagues has demonstrated that Nedd4-2 facilitates rapid endocytosis of proteolytically cleaved $\mathrm{ENaC}$, leading to increased degradation of the cleaved, active channel [97]. This endocytosis was dependent on the presence of the PY motifs of ENaC. In accord, mutations of these PY motifs (mimicking those in Liddle syndrome) or mutation of the ubiquitin acceptors sites in $\mathrm{ENaC}$ increased the fraction of cleaved, active channels at the plasma membrane [108]. In agreement with these observation, Staub and colleagues have recently demon- strated that Usp-45-mediated de-ubiquitylation of ENaC enhances its proteolytic cleavage (on $\alpha$ and $\gamma \mathrm{ENaC}$ ), thus stimulating its activation [171]. These data thus suggest that ubiquitylation may regulate the conformation of the extracellular domain, and likely the accessibility of protease sites for cleavage.

The strong reliance of ENaC on Nedd4-2-mediated downregulation (channel ubiquitylation and endocytosis) has been a long-standing puzzle, since intuitively it would be much faster to close the channel rather than to inernalize it when its function is no longer needed; the recent findings that protease cleavage releases a segment of the channel (the inhibitory tract), leading to irreversible opening of the channel, helps explain this puzzle, since such constitutively active channels have to be removed from the plasma membrane to stop the influx of $\mathrm{Na}^{+}$.

Regulation of endocytosis of other ion channels by Nedd 4 family ubiquitin ligases

Following the discovery of ENaC: Nedd4/Nedd4-2 interactions, several groups have identified PY motifs in numerous other channels, prompting investigations into their potential regulation by Nedd4 proteins, as described below.

\section{Voltage-gated $\mathrm{Na}^{+}$channels}

Voltage-gated $\mathrm{Na}^{+}$channels, $\mathrm{Na}_{\mathrm{v}} \mathrm{s}$, are responsible for generating action potential in excitable cells, primarily in cardiac and neuronal tissues. They are comprised of poreforming $\alpha$ subunits assembled together with regulatory $\beta$ subunits [230]. These channels play a critical role in cardiac and neuronal functions, and mutations in some of them cause human diseases [230]. For example, mutations in $\mathrm{Na}_{\mathrm{v}} 1.5$ (SCN5A) that impair its inactivation in the heart lead to long QT (type 3) and Brugada syndromes [105] and inactivation of the Scn5a gene in mice leads to cardiac function defects [152]. Likewise, gain of function mutations in $\mathrm{Na}_{\mathrm{v}} 1.1$ (SCN1A) causes generalized epilepsy with febrile seizures (GEFS+) by enhancing inward $\mathrm{Na}^{+}$current in brain neurons [52]. Of the ten known $\mathrm{Na}_{\mathrm{v}} \mathrm{s}$, seven $\left(\mathrm{Na}_{\mathrm{v}} 1.1-1.3\right.$ and $\mathrm{Na}_{\mathrm{v}} 1.5-1.8$ ) possess a conserved PY motif (PPSYxxØ) at the cytosolic $\mathrm{C}$ termini of their $\alpha$ subunits $[61,170]$. Much like $\mathrm{ENaC}$, cell surface stability of the cardiac $\mathrm{Na}_{\mathrm{v}} 1.5$ was demonstrated to be negatively regulated by Nedd4-2, a process that requires the PY motif of this channel, as well as active Nedd4-2, suggesting channel ubiquitylation regulates its endocytosis [1, 204]. Similar results were obtained for other PY-motif containing $\mathrm{Na}_{\mathrm{v}} \mathrm{s}, \mathrm{Na}_{\mathrm{v}} 1.2,1.3$, 1.7 and $1.8[61,170]$; while Nedd4-2 was the predominant E3 ligase involved in suppressing these $\mathrm{Na}_{\mathrm{v}} \mathrm{s}, \mathrm{WWP} 2$ and Nedd4-1 may contribute to the regulation as well. A recent 
search for NEDD4-2 variants in 250 families with photosensitive generalized epilepsy (IGE) identified several such variants, although their expression in Xenopus oocytes did not affect their ability to interact with $\mathrm{Na}_{\mathrm{v}} 1.2$, nor alter channel function [44], suggesting that the physiological significance of these variants need to be further explored.

Recently it was shown that Nav1.6 is regulated by Nedd4-2 as well. Interestingly Nedd4-2 appears to interact with 2 motifs, one of which is a PGSP motif that needs to be phosphorylated by the p38 kinase in order to interact with Nedd4-2 [66].

\section{Voltage-gated $\mathrm{K}^{+}$channels and $\mathrm{Ca}^{2+}$ channels}

Voltage-gated $\mathrm{K}^{+}$channels comprise several subfamilies, including the KCNQ $\left(\mathrm{K}_{\mathrm{v}} 7\right)$, KCNA $\left(\mathrm{K}_{\mathrm{v}} 1\right), \mathrm{KCNB}\left(\mathrm{K}_{\mathrm{v}} 2\right)$ and others. These channels play a key role in neuronal excitability, and mutations in several of them cause neurological and cardiac impairments. For example, loss of function mutations in KCNQ2 $\left(\mathrm{K}_{\mathrm{v}} 7.2\right)$ or KCNQ3 $\left(\mathrm{K}_{\mathrm{v}} 7.3\right)$ cause epilepsy [164], while such mutations in KCNQ1 (Kv7.1) or its associated subunit KCNE1 cause Long QT (Type I) syndrome (cardiac ventricular arrhythmia) [105].

KCNQ1 possesses a PY motif (LPxYxxØ) at its intracellular $\mathrm{C}$ terminus, which is conserved across species and serves as binding site for human Nedd4-2, Nedd4-1, or WWP2. Accordingly, the current produced by the KCNQ1/ KCNE1 channel $\left(I_{k s}\right)$ is reduced by overexpression of these Nedd4 family members and is suppressed by their catalytically inactive mutants, or upon mutating the PY motif of KCNQ1 [95]. These Nedd4 family members thus affect channel ubiquitylation and internalization. Likewise, the muscarinic-sensitive $\mathrm{K}^{+}$current (M-current), mediated by heterotetrameric channels consisting of KCNQ3 associated with either KCNQ2 or KCNQ5 (i.e., KCNQ2/3 or KCNQ3/5), are regulated by Nedd4-2, ubiquitylation and Sgk1 $[50,175]$. The C termini of KCNQ2 and KCNQ3 contain an atypical "PY motif" (PPxPPY). However, while Nedd4-2 can bind the $C$ termini of these channel subunits, binding is not mediated via this motif [50]; thus, Nedd4-2 either interacts with another C-terminal sequence, or via an adapter protein. Active Nedd4-2 is required to suppress function of these channels, suggesting that ubiquitylation regulates their stability, likely at the cell surface [50]. Similar to $\mathrm{ENaC}$, the regulation of KCNQ2/3 and KCNQ3/ 5 via Nedd4-2 can be modulated by Sgk1 mediated phosphorylation of this E3 ligase [175].

The $\mathrm{K}^{+}$channels $\mathrm{K}_{\mathrm{v}} 1.3$ (KCNA3) and $\mathrm{K}_{\mathrm{v}} 1.5$ (KCNA5), which are stimulated by insulin or IGF-1, have been demonstrated to be inhibited by Nedd4-2 and up-regulated by Sgk1, which suppresses Nedd4-2, using Xenopus oocyte expression system [17, 79]. Nedd4-2 was shown to ubiquitylate $\mathrm{K}_{\mathrm{v}} 1.5$, thus inducing its endocytosis [17]. Interestingly, while Kv4.3 (KCND3) assembled with its accessory protein KChiP, was stimulated by Sgk1, this stimulation was not mediated via Nedd4-2 and was not associated with increased cell surface stability of this channel [10].

In addition to the above-described examples, a recent proteome array screen aimed at identifying substrates for mammalian Nedd4 protein, identified other $\mathrm{K}^{+}$channels as in vitro substrates for Nedd4-2: KCNAB1, KCNAB3 and KCNB1 $\left(\mathrm{K}_{\mathrm{v}} 2.1\right)$, with the latter two possessing PY motifs [155]. The role of these in vitro substrates needs to be examined in vivo now to test if these channels are regulated by Nedd4-2 in a physiological setting.

The same proteome array screen also identified the $\mathrm{Ca}^{2+}$ channel, CACNB1, as a substrate for Nedd4-2, an observation that was also validated in mammalian cells [155]. Interestingly, a subset of the TRP $\mathrm{Ca}^{2+}$ channel, such as TRPV4 and TRPC4, have been shown to be ubiquitylated and AIP4/Itch, a Nedd4-like protein; this ubiquitylation leads to endocytosis of these channels [213], thus suppressing their function. This AIP4 - mediated ubiquitylation requires the $\mathrm{N}$ terminal region of the TRP channels, although a variant PY motif (GPxYxxL) present within the $\mathrm{N}$-terminus was dispensable [213]. Recently, evidence was also provided that the calcium channel TRPV6 may be regulated by Nedd4-2 [232].

Collectively, these results point to a major role of Nedd4 proteins, primarily Nedd4-2, in promoting ubiquitylation and endocytosis of numerous cell surface cation channels, thus suppressing their function.

\section{$\mathrm{Cl}^{-}$channels/transporters}

Much like cation channels, several anion channels have been shown to be regulated by Nedd 4 family members, with $\mathrm{Cl}$ - channels $(\mathrm{ClC})$ family most extensively studied. The $\mathrm{ClC}$ family comprises both $\mathrm{Cl}^{-}$channels and $\mathrm{Cl}^{-} / \mathrm{H}^{+}$ antiporters $[94,215]$. $\mathrm{ClC} 5$ is a $\mathrm{Cl}^{-} / \mathrm{H}^{+}$antiporter that is expressed primarily in endosomal membranes in the proximal tubules and is responsible for endosomal acidification, a role it carries out in collaboration with V-ATPase. This acidification is required for re-absorption of small molecule proteins, minerals and vitamins by the kidney [72]. Loss of function mutations in CLC5 leads to Dent disease, a disorder characterized by excessive loss of proteins (proteinuria), calcium and phosphate in the urine, resulting in kidney stones [220]. In accord, ClC5 knockout mice exhibit proteinuria and defects in both receptor mediated and fluid phase endocytosis, resembling Dent disease in humans [156]. A carboxy terminal PY motif (PPLPPY) was identified earlier in $\mathrm{ClC5}$, and shown to be required for endocytosis of the channel [176]. It was 
postulated that WWP2 could be mediating the endocytosis of ClC5 by interacting with its PY motif [176], although a later study proposed that Nedd4-2 is the E3 ligase involved [84]. In the latter study, Nedd4-2 was shown to regulate ClC5 ubiquitylation and albumin uptake into endosomes. Similar to $\mathrm{ClC} 5, \mathrm{ClC} 2$ was also shown to be regulated by Nedd4-2 [150]. ClC2, a bone fide $\mathrm{Cl}^{-}$channel, is ubiquitously expressed and is localized to the plasma membrane. Disruption of $\mathrm{ClC} 2$ in mice causes testicular and retina degeneration, as well as wide-spread vacuolation in the white matter of the CNS, suggesting that regulation of ionic environment via $\mathrm{ClC} 2$ in these cells/tissues is necessary for their normal maintenance $[16,21]$. One study also suggested that the $C l C 2$ gene is included in a chromosomal region associated with susceptibility to epilepsy [172], however, the putative role of $\mathrm{ClC} 2$ in this increased susceptibility needs to be further investigated. $\mathrm{ClC} 2$ was shown to be positively regulated by Sgk1-3, and negatively regulated by Nedd4-2, which reduces it cell surface expression [150], although a direct interaction between Nedd4-2 and $\mathrm{ClC} 2$ was not demonstrated in that study, nor does $\mathrm{ClC} 2$ possess a $\mathrm{PY}$ motif. $\mathrm{ClC}-\mathrm{Ka}$ is another bone fide $\mathrm{Cl}^{-}$channel that along with $\mathrm{ClC}-\mathrm{Kb}$ is a basolateral channel expressed in the ascending loop of Henley and regulates $\mathrm{Na}^{+}, \mathrm{Cl}^{-}$, and fluid absorption. In accord, knockout of Clckl (ClC-Ka) in mice leads to severe urinary loss [200]. The $\mathrm{ClC}-\mathrm{Ka}$ and $\mathrm{ClC}-\mathrm{Kb}$ channels require co-expression of an accessory protein, barttin, to become functional [53]. Mutations in BSND (the barttin gene) causes a severe form of Bartter's syndrome, characterized by severe renal salt wasting and deafness [15]. Interestingly, Barttin contains a PY motif and its mutation enhances activity of the $\mathrm{ClC}-\mathrm{Kb} / \mathrm{Barttin}$ channel [53]. It was subsequently shown that Nedd4-2 can suppress ClC$\mathrm{Ka} /$ Barttin function when co-expressed in Xenopus oocytes, an effect prevented upon mutation of the PY motif in barttin [51]. Here, too, Sgk1 and Sgk3 were able to phosphorylate Nedd4-2 and block its suppression of the channel.

In addition to the $\mathrm{ClC}$ family, other $\mathrm{Cl}^{-}$channels appear to be regulated by Nedd 4 proteins. The Tweety (TTYH) family are maxi $\mathrm{Cl}^{-}$channels that includes three members in humans, TTYH1-3, with TTYH2 and TTYH3 (but not TTYH1) activated by $\mathrm{Ca}^{2+}$ [195]. TTYH2 and TTYH3 possess a PY motif, which a recent study has suggested is involved in binding to Nedd4-2; accordingly, Nedd4-2 was shown to ubiquitylate TTYH2 and regulate its cell surface stability [77]. An additional $\mathrm{Cl}^{-}$channel, CLIC2 (intracellular $\mathrm{Cl}^{-}$channel 2), could potentially be another target for regulation by Nedd4-2, as it was identified in the abovedescribed proteome array screen as a target for ubiquitylation by Nedd4-2 (and Nedd4-1) and possesses a PY motif [155].
The suppression of channel function by Nedd4 family members was also reported in several transporters in addition to ClC5. For example, the excitatory amino acid transporter EAAT2 (which does not contain a PY motif) was shown to be suppressed by Nedd4-2 and stimulated by Sgk1-3 or Akt [18]. Likewise, the divalent metal transporter, DMT1, was shown to be regulated by WWP2 and Nedd4-2; this was mediated by recruitment of the adapter protein Ndfip1 [59, 83], as described below. Moreover the connexin 43, which contains a PY-motif, was also demonstrated to be regulated by Nedd4-2 [115] by one group, whereas the Staub's group found that the extened PY-motif was rather part of a tyrosine-based sorting signal not regulated by Nedd4 ubiquitin-protein ligases [197].

In addition to the regulation of CFTR and its $\triangle$ F508CFTR trafficking mutant by ERAD in the biosynthetic pathway (described above), it was recently found that "rescued" $\Delta$ F508-CFTR that is able to reach the plasma membrane exhibits a short half life there and is targeted for degradation by the E3 ligase CHIP, with the aid of several chaperones and co-chaperones [146].

Overall, it appears that cell surface stability of numerous ion channels and transporters is regulated by Nedd4 proteins, mainly Nedd4-2 (and sometimes WWP2, Nedd4-1, or AIP4). This regulation often involves the Sgk/Akt family of kinases, which phosphorylate Nedd4-2 thus preventing it from interacting with its targets. The regulation by these kinases (and others) help link Nedd4-2 and the channels its ubiquitylates to hormone and growth factors signaling (e.g. aldosterone, vasopressin, insulin), which play critical roles in maintaining homeostasis of ion and fluid composition and overall normal physiological functions of the organism.

Regulation of endocytosis of channels/transporters by other (or unknown) E3 ligases

While most studies to date have focused on the regulation of ion channels/transporters by Nedd4 family proteins, several others have described regulation of such channels by different (or still unknown) E3 ligases. For example, function of the ENaC-related channel, ASIC, is suppressed by the E3 ligase Parkin, in a process that includes the adapter protein, PICK1 [96] (see below). Another example is the water channel AQP2, which is oligo-ubiquitylated with $\mathrm{ub}(\mathrm{K} 63)$ on one Lys residue upon withdrawal of vasopressin/forskolin or PKC activation, which targets it for endocytosis, MVB sorting and lysosomal degradation [98]. The E3 ligase that mediates this reaction is not yet known.

In cilia of the mammalian kidney and sensory cilia in Caenorhabditis elegans, polycystin-1 (PC1, encoded by PKD1) and PC2 (TRPP2, encoded by PKD2) function 
together as a mechanosensory $\mathrm{Ca}^{2+}$ channel. Using $C$. elegans, it was recently shown that this channel complex is sorted for lysosomal degradation by the STAM-Hrs system in a process that involves mono-ubiquitylation of PC2 by as yet an unknown E3 ligase [85]. The physiological importance of these channels and their regulation is underscored by the observation that mutations in PKD1 or PKD2 cause autosomal dominant polycystic kidney disease (ADPKD), an end stage renal disease [91]. In a separate study, it was discovered that knockout of the transcription factor TAZ in mice led to increased levels of PC2 [198]; upon phosphorylation, TAZ interacts with $\mathrm{SCF}^{\beta-\mathrm{Trcp}}$ to form an E3 ligase complex, which then targets $\mathrm{PC} 2$ for degradation by the proteasome [198]. It is unlikely that the TAZ:SCF ${ }^{\beta-T r c p}$ complex (and polyubiquitylation) is also involved in targeting of the PC1:PC2 channel for sorting by STAM-Hrs and lysosomal degradation, and thus suggests that regulation of this $\mathrm{Ca}^{2+}$ channel is mediated by more than one E3 ligase. In addition to regulation by E3 ligases, a role for DUBs was also described for the regulation of TRP channels. The TRPA1 channel, which responds to cold temp and pungent compounds, was shown to associate with the DUB CYLD, which is a tumor suppressor; this leads to deubiquitylation of TRPA1 and its stabilization, thus connecting TRPA1 to oncogenesis [193].

Analogous to regulation of several $\mathrm{K}^{+}$channels by Nedd4 family members (described above), a recent paper describes the suppression of ROMK1 (Kir1.1) by the RING E3 ligase POSH [123]. POSH binds the $\mathrm{N}$ terminus of ROMK1, leading to channel ubiquitylation via the POSHRING domain and endocytosis via a clathrin-independent pathway [123].

\section{Ubiquitin-mediated regulation of ion channels and transporters via adapter proteins}

In most of the examples described above, Nedd4-2 (or its family relatives) was able to directly interact with its target channel/transporter, especially in those cases where these transmembrane proteins possess a PY motif that can bind the WW domains of Nedd4 proteins (eg in $\mathrm{ENaC}$, several $\mathrm{Na}_{\mathrm{v}} \mathrm{s}, \mathrm{K}^{+}$channels and $\mathrm{ClC} 5$ ). In other cases, such interactions may be indirect, via adapter proteins, which themselves possess PY motifs (Fig. 4). This has been observed earlier in yeast TM proteins that are regulated by Rsp5, the $S$. Cerevisae orthologue of Nedd4/Nedd4-2. For example, Bul1 and Bul2 serve as adapters to connect between Rsp5 and the general amino acid permease, Gap1, thus facilitating Rsp5-mediated ubiquitylation of Gap1 and its subsequent endocytosis from the PM or sorting from the Golgi to vacuoles [189].
Likewise, several arrestin related proteins (ARTs) were recently identified as PY motif-containing adapters that connect between Rsp5 and numerous PM proteins (mostly transporters), thus promoting Rsp5-mediated ubiquitylation and endocytosis of these proteins [122]; for reasons not yet clear, the adapter proteins themselves are target for Rsp5-mediated ubiquitylation [73, 122], which is required for their function. An interesting example, also conserved in mammals, is the adapter Bsd2. One function of this ER protein is to regulate ubiquitin-mediated trafficking to the $\mathrm{PM}$ of the metal ion transporters, Smf1 and Smf2, in yeast [124]. The mammalian homologues of Bsd2 are Ndfip1 (N4WBP5) and Ndfip2 (MDWBP5a), and are PY motifcontaining adapters for Nedd4 proteins that reside in intracellular vesicles. Similar to Bsd2 in yeast, they serve as adapters to connect between WWP2 and the divalent metal transporter DMT1 in mammals [59]. DMT1 is responsible for iron uptake in enterocytes and its release from vesicles in hepatocytes. Ndfip $1 \& 2$ facilitate ubiquitylation of DMT1 by WWP2, resulting in degradation of this metal transporter (Fig. 4A). Accordingly, knockout of Ndfip1 in mice leads to increased DMT1 activity and hepatic iron accumulation [59], suggesting a key role for this adapter in regulating iron homeostasis. More recently, Ndfip1 was shown to protect human neurons from iron and cobalt toxicity, and knockdown or knockout of this adapter resulted in accumulation of these metals in neurons [83]; In this case, Nfdip1 serves as an adapter to connect neuronal DMT1 to Nedd4-2.

As indicated above, the vasopressin-inducible DUB, Usp-10, enhances ENaC abundance and function at the plasma membrane [23]. Here, however, Usp10 does not directly de-ubiquitylate $\mathrm{ENaC}$, but rather a third partner, sorting nexin 3 (SNX3), a protein that when co-expressed with $\mathrm{ENaC}$ increases cell-surface stability of the channel. Thus, Usp-10 mediated de-ubiquitylation of SNX3 leads to increased stability of SNX3, which in turn promotes $\mathrm{ENaC}$ stabilization [23]. (Fig. 4B).

ASIC, the acid-sensing ion channel that is expressed in neurons, belongs to the $\mathrm{ENaC} /$ degenerin family, but lacks the $\mathrm{C}$-terminal region present in $\mathrm{ENaC}$ that contains a PY motif (and thus does not interact with Nedd4-2). Instead, ASIC binds PICK1, a PDZ - containing protein that normally potentiates ASIC function following PKC stimulation. PICK1 is a substrate for Parkin, a RING finger E3 ligase, which mono-ubiquitylates PICK1; this mono-ubiquitylation (and thus protection from proteasomal degradation) appears to block the ability of PICK1 to potentiate ASIC [96] (Fig. 4C). In accord, loss of parkin in hippocampal neurons by its knockout in mice leads to enhanced ASIC activation, thus potentially promoting neuro-degeneration, as seen in Parkinson's disease [96]. 
A.

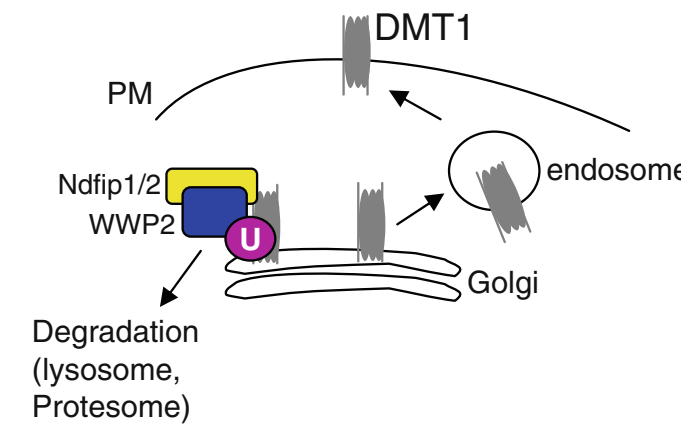

C.

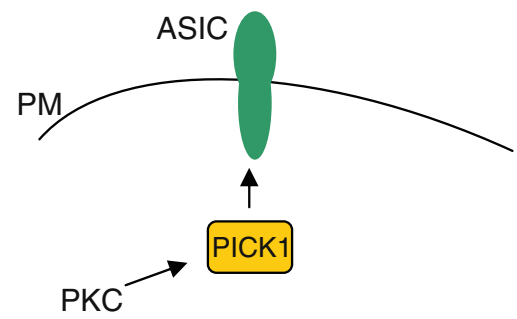

Fig. 4 Role of adapter proteins in ubiquitin-mediated regulation of ion transporters or channels. A The metal ion transporter DMT1 is targeted to the plasma membrane PM via recycling endosomes. This delivery can be inhibited by the WWP2, which is recruited to DMT1 at the Golgi via the adapter proteins Ndfip1/2 (that possess PY motifs), leading to ubiquitylation of the transporter and its degradation

\section{Regulation of ion channels by UBLs (SUMO)}

As indicated in the "Introduction" section, posttranslational modification by UBLs has emerged as an important factor in the regulation of function of numerous cellular proteins. One of the better-studied UBLs is SUMO. Several recent studies have focused on the role of SUMOylation in regulating ion channels.

The $\mathrm{Ca}^{2+}$ channel TRPM4, expressed in cardiac Purkinje fibers, was recently demonstrated to harbor a mutation, E17K, which is associated with progressive familial heart block type I (PFHB1), an autosomal dominant disease; the mutant channel exhibits an increased channel SUMOylation and accumulation at the plasma membrane, leading to enhanced function of this channel [110]. It was proposed that such enhanced SUMOylation prevents channel ubiquitylation and endocytosis, although this hypothesis was not experimentally tested (i.e., ubiquitylation of the mutant vs. WT channel was not investigated).

Several $\mathrm{K}^{+}$channels were also reported to be regulated by SUMOylation. The K2P1 (TWIK1) leak channel was previously shown to be a weak (or inactive) channel [70, 113, 148]. A report by Goldstein and colleagues then demonstrated that this channel is maintained in an inactive state by SUMOylation on one specific Lys (K274); upon de-SUMOylation by SENP-1, the channel becomes active,
B.
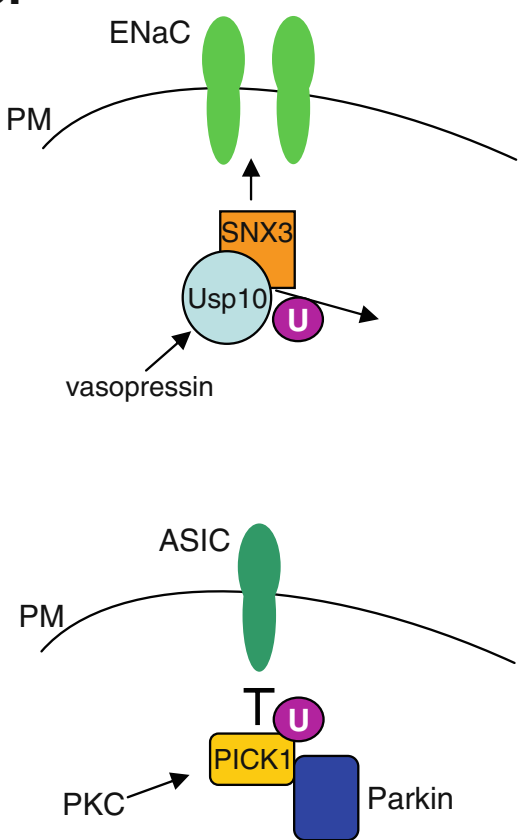

by the lysosome and/or proteasome. B The vasopressin-sensitive DUB, Usp10, de-ubiquitylates sorting nexin 3 (SNX3), a process that stabilizes SNX3. SNX3, in turn, leads to increased stabilization of $\mathrm{ENaC}$ at the plasma membrane. C PKC-stimulated potentiation of ASIC function mediated by PICK1 (left panel) is inhibited by monoubiquitylation of PICK1 by Parkin (right panel). $U$ ubiquitin

exhibiting $\mathrm{K}^{+}$selectivity and sensitivity to extracellular $\mathrm{pH}$ [161]. A subsequent paper challenged these findings, suggesting that the K274 residue may not be involved in SUMOylation of the channel [56]. Recently it has been shown that one SUMO is sufficient to silence the K2P1 channel [157]. More recently, other studies provided evidence for SUMO modification of other $\mathrm{K}^{+}$channels. $\mathrm{K}_{\mathrm{v}} 1.5$, which mediates the $\mathrm{I}(\mathrm{kur})$ depolarizing current in human atrial myocytes, was shown to be directly SUMOylated by Ubc9 (the E2 for SUMOylation reaction) at two sites [11]; removal of this SUMO conjugation by SENP2 or by mutating the SUMOylation sites led to hyperpolarizing shift in voltage dependence of steady-state inactivation of the channel. The voltage-dependent channel $\mathrm{K}_{\mathrm{v}} 2.1$ regulates pancreatic beta cell excitability and insulin secretion. Recent work demonstrated that SUMOylation of Kv1.5 inhibits its native current by accelerating channel inactivation and inhibiting recovery from inactivation, resulting in decreased firing frequency [40]. These effects were augmented by overexpression of Ubc9 and alleviated by SENP1. It remains to be investigated how exactly (by what mechanisms) does SUMOylation of $\mathrm{K}^{+}$channels, such as $\mathrm{K}_{\mathrm{v}} 1.5$ or $\mathrm{K}_{\mathrm{v}} 2.1$, regulate their biophysical properties and activity.

It is curious that $\mathrm{KChAP}$, which was originally described as a chaperone that increases protein expression of several 
$\mathrm{K}^{+}$channels, was later identified as PIAS3 $\beta$, a SUMO E3 ligase [158]. So far it is not known if/how SUMOylation may affect the chaperone activity of KChAP/PIAS3 $\beta$ towards these channels.

Thus, relative to ubiquitylation of ion channels, much less is known about the mechanisms by which SUMOylation regulates function of such channels, nor is it known (yet) whether modifications by other UBLs can affect ion channel function.

\section{Summary/perspectives}

Over the past 15 years much has been learned about the role of the ubiquitin system in regulating ion channels and transporters, particularly during their processing in the ER and during endocytosis or sorting to MVBs and the lysosome. Much of the work has focused on the Nedd4 family of E3 ligases, and more recently on other E3 ligases, DUBs and several adapter proteins. In spite of these great advances, there are critical outstanding issues that need to be addressed:

(a) To date, many studies demonstrating regulation of endocytosis of ion channels and transporters by E3s, especially Nedd 4 family members, have been carried out by overexpression in Xenopus oocytes or tissue culture cells. It is essential that these initial studies are validated in vivo in the relevant physiological tissues. In that regard, recent advances in studying the role of Nedd4-2 in regulating ENaC in mouse kidney (and lung) represent important advances, and hopefully will be followed by similar studies on other ion channels/ transporters.

(b) So far, in most studies the nature of the ubiquitin attachments to the ion channels/transporter, especially at the plasma membrane, is not clear. For example, are the channels/transporters mono-, oligo- or poly ubiquitylated? Are the ubiquitins attached utilize K63, K48 (or others) linkages? Accordingly, is the cargo channel/transporter targeted to the lysosome, proteasome or both? Likewise, very little is known about the functions of UBLs in regulating ion transport, nor the role of other modifications, such as acetylation.

(c) As detailed in the review, there are numerous diseases that are associated with malfunction of some of the ion channels described, including defects that involve the ubiquitin system. To develop drugs that targets these defects, it would be useful to solve the structure of the E3 ligase involved in complex with their cognate channel/ transporter, or at least the binding interface of these binding partners. Given the recent advances in solving structures of transmembrane proteins, this difficult task may now become a reality. Such an approach could lead to the development of compounds that block or enhance these interactions in a specific manner, which could have an important therapeutic value.

Acknowledgements Work from the authors' laboratories described in this review was funded by the Canadian Institute of Health Research and the Canadian CF Foundation (to DR), and the Swiss National Science Foundation (to OS).

\section{References}

1. Abriel H, Kamynina E, Horisberger JD, Staub O (2000) Regulation of the cardiac voltage-gated $\mathrm{Na}+$ channel $(\mathrm{H} 1)$ by the ubiquitin-protein ligase Nedd4. FEBS Lett 466:377-380

2. Abriel H, Loffing J, Rebhun JF, Pratt JH, Schild L, Horisberger JD, Rotin D, Staub O (1999) Defective regulation of the epithelial $\mathrm{Na}+$ channel by Nedd4 in Liddle's syndrome. J Clin Invest 103:667-673

3. Abriel H, Staub O (2005) Ubiquitylation of ion channels. Physiol Bethesda 20:398-407

4. Adams CM, Snyder PM, Welsh MJ (1997) Interactions between subunits of the human epithelial sodium channel. J Biol Chem 272:27295-27300

5. Ahner A, Nakatsukasa K, Zhang H, Frizzell RA, Brodsky JL (2007) Small heat-shock proteins select deltaF508-CFTR for endoplasmic reticulum-associated degradation. Mol Biol Cell 18:806-814

6. Almaca J, Kongsuphol P, Hieke B, Ousingsawat J, Viollet B, Schreiber R, Amaral MD, Kunzelmann K (2009) AMPK controls epithelial $\mathrm{Na}(+)$ channels through Nedd4-2 and causes an epithelial phenotype when mutated. Pflugers Arch 458:713-721

7. Alvarez de la Rosa D, Zhang P, Naray-Fejes-Toth A, Fejes-Toth G, Canessa CM (1999) The serum and glucocorticoid kinase sgk increases the abundance of epithelial sodium channels in the plasma membrane of Xenopus oocytes. J Biol Chem 274:37834 37839

8. Araki N, Umemura M, Miyagi Y, Yabana M, Miki Y, Tamura K, Uchino K, Aoki R, Goshima Y, Umemura S, Ishigami T (2008) Expression, transcription, and possible antagonistic interaction of the human Nedd4L gene variant: implications for essential hypertension. Hypertension 51:773-777

9. Auberson M, Hoffmann-Pochon N, Vandewalle A, Kellenberger S, Schild L (2003) Epithelial $\mathrm{Na}+$ channel mutants causing Liddle's syndrome retain ability to respond to aldosterone and vasopressin. Am J Physiol Ren Physiol 285:F459-F471

10. Baltaev R, Strutz-Seebohm N, Korniychuk G, Myssina S, Lang F, Seebohm G (2005) Regulation of cardiac shal-related potassium channel Kv 4.3 by serum- and glucocorticoidinducible kinase isoforms in Xenopus oocytes. Pflugers Arch 450:26-33

11. Benson MD, Li QJ, Kieckhafer K, Dudek D, Whorton MR, Sunahara RK, Iniguez-Lluhi JA, Martens JR (2007) SUMO modification regulates inactivation of the voltage-gated potassium channel Kv1.5. Proc Natl Acad Sci USA 104:1805-1810

12. Bertog M, Cuffe JE, Pradervand S, Hummler E, Hartner A, Porst M, Hilgers KF, Rossier BC, Korbmacher C (2008) Aldosterone responsiveness of the epithelial sodium channel $(\mathrm{ENaC})$ in colon is increased in a mouse model for Liddle's syndrome. J Physiol 586:459-475

13. Bhalla V, Daidie D, Li H, Pao AC, LaGrange LP, Wang J, Vandewalle A, Stockand JD, Staub O, Pearce D (2005) Serum- 
and glucocorticoid-regulated kinase 1 regulates ubiquitin ligase neural precursor cell-expressed, developmentally down-regulated protein 4-2 by inducing interaction with 14-3-3. Mol Endocrinol 19:3073-3084

14. Bhalla V, Oyster NM, Fitch AC, Wijngaarden MA, Neumann D, Schlattner U, Pearce D, Hallows KR (2006) AMP-activated kinase inhibits the epithelial $\mathrm{Na}+$ channel through functional regulation of the ubiquitin ligase Nedd4-2. J Biol Chem 281:26159-26169

15. Birkenhager R, Otto E, Schurmann MJ, Vollmer M, Ruf EM, Maier-Lutz I, Beekmann F, Fekete A, Omran H, Feldmann D, Milford DV, Jeck N, Konrad M, Landau D, Knoers NV, Antignac C, Sudbrak R, Kispert A, Hildebrandt F (2001) Mutation of BSND causes Bartter syndrome with sensorineural deafness and kidney failure. Nat Genet 29:310-314

16. Blanz J, Schweizer M, Auberson M, Maier H, Muenscher A, Hubner CA, Jentsch TJ (2007) Leukoencephalopathy upon disruption of the chloride channel ClC-2. J Neurosci 27:6581-6589

17. Boehmer C, Laufer J, Jeyaraj S, Klaus F, Lindner R, Lang F, Palmada M (2008) Modulation of the voltage-gated potassium channel Kv1.5 by the SGK1 protein kinase involves inhibition of channel ubiquitination. Cell Physiol Biochem 22:591-600

18. Boehmer C, Palmada M, Rajamanickam J, Schniepp R, Amara S, Lang F (2006) Post-translational regulation of EAAT2 function by co-expressed ubiquitin ligase Nedd4-2 is impacted by SGK kinases. J Neurochem 97:911-921

19. Bonifacino JS, Cosson P, Klausner RD (1990) Colocalized transmembrane determinants for ER degradation and subunit assembly explain the intracellular fate of TCR chains. Cell 63:503-513

20. Bonny O, Chraibi A, Loffing J, Jaeger NF, Grunder S, Horisberger JD, Rossier BC (1999) Functional expression of a pseudohypoaldosteronism type I mutated epithelial $\mathrm{Na}+$ channel lacking the pore-forming region of its alpha subunit. J Clin Invest 104:967-974

21. Bosl MR, Stein V, Hubner C, Zdebik AA, Jordt SE, Mukhopadhyay AK, Davidoff MS, Holstein AF, Jentsch TJ (2001) Male germ cells and photoreceptors, both dependent on close cell-cell interactions, degenerate upon $\mathrm{ClC}-2 \mathrm{Cl}(-)$ channel disruption. EMBO J 20:1289-1299

22. Boucher RC (2007) Airway surface dehydration in cystic fibrosis: pathogenesis and therapy. Annu Rev Med 58:157-170

23. Boulkroun S, Ruffieux-Daidie D, Vitagliano JJ, Poirot O, Charles RP, Lagnaz D, Firsov D, Kellenberger S, Staub O (2008) Vasopressin-inducible ubiquitin-specific protease 10 increases $\mathrm{ENaC}$ cell surface expression by deubiquitylating and stabilizing sorting nexin 3. Am J Physiol Ren Physiol 295:F889-F900

24. Bruns JB, Carattino MD, Sheng S, Maarouf AB, Weisz OA, Pilewski JM, Hughey RP, Kleyman TR (2007) Epithelial Na+ channels are fully activated by furin- and prostasin-dependent release of an inhibitory peptide from the gamma-subunit. J Biol Chem 282:6153-6160

25. Bruns JB, Hu B, Ahn YJ, Sheng S, Hughey RP, Kleyman TR (2003) Multiple epithelial $\mathrm{Na}+$ channel domains participate in subunit assembly. Am J Physiol Ren Physiol 285:F600-F609

26. Buck TM, Kolb AR, Boyd CR, Kleyman TR, Brodsky JL (2010) The endoplasmic reticulum-associated degradation of the epithelial sodium channel requires a unique complement of molecular chaperones. Mol Biol Cell 21:1047-1058

27. Butterworth MB, Edinger RS, Ovaa H, Burg D, Johnson JP, Frizzell RA (2007) The deubiquitinating enzyme UCH-L3 regulates the apical membrane recycling of the epithelial sodium channel. J Biol Chem 282:37885-37893

28. Canessa CM, Schild L, Buell G, Thorens B, Gautschi I, Horisberger JD, Rossier BC (1994) Amiloride-sensitive epithe- lial $\mathrm{Na}+$ channel is made of three homologous subunits. Nature 367:463-467

29. Caramelo JJ, Parodi AJ (2007) How sugars convey information on protein conformation in the endoplasmic reticulum. Semin Cell Dev Biol 18:732-742

30. Carattino MD, Edinger RS, Grieser HJ, Wise R, Neumann D, Schlattner U, Johnson JP, Kleyman TR, Hallows KR (2005) Epithelial sodium channel inhibition by AMP-activated protein kinase in oocytes and polarized renal epithelial cells. J Biol Chem 280:17608-17616

31. Carattino MD, Hughey RP, Kleyman TR (2008) Proteolytic processing of the epithelial sodium channel gamma subunit has a dominant role in channel activation. J Biol Chem 283:25290 25295

32. Carattino MD, Passero CJ, Steren CA, Maarouf AB, Pilewski JM, Myerburg MM, Hughey RP, Kleyman TR (2008) Defining an inhibitory domain in the alpha-subunit of the epithelial sodium channel. Am J Physiol Ren Physiol 294:F47-F52

33. Carvalho P, Goder V, Rapoport TA (2006) Distinct ubiquitinligase complexes define convergent pathways for the degradation of ER proteins. Cell 126:361-373

34. Chang SS, Grunder S, Hanukoglu A, Rosler A, Mathew PM, Hanukoglu I, Schild L, Lu Y, Shimkets RA, Nelson-Williams C, Rossier BC, Lifton RP (1996) Mutations in subunits of the epithelial sodium channel cause salt wasting with hyperkalaemic acidosis, pseudohypoaldosteronism type 1 . Nat Genet 12:248-253

35. Chen B, Mariano J, Tsai YC, Chan AH, Cohen M, Weissman AM (2006) The activity of a human endoplasmic reticulumassociated degradation E3, gp78, requires its Cue domain, RING finger, and an E2-binding site. Proc Natl Acad Sci USA 103:341-346

36. Chen SY, Bhargava A, Mastroberardino L, Meijer OC, Wang J, Buse P, Firestone GL, Verrey F, Pearce D (1999) Epithelial sodium channel regulated by aldosterone-induced protein sgk. Proc Natl Acad Sci USA 96:2514-2519

37. Cheng SH, Gregory RJ, Marshall J, Paul S, Souza DW, White GA, O'Riordan CR, Smith AE (1990) Defective intracellular transport and processing of CFTR is the molecular basis of most cystic fibrosis. Cell 63:827-834

38. Christianson JC, Green WN (2004) Regulation of nicotinic receptor expression by the ubiquitin-proteasome system. EMBO J 23:4156-4165

39. Dahlmann A, Pradervand S, Hummler E, Rossier BC, Frindt G, Palmer LG (2003) Mineralocorticoid regulation of epithelial $\mathrm{Na}+$ channels is maintained in a mouse model of Liddle's syndrome. Am J Physiol Ren Physiol 285:F310-F318

40. Dai XQ, Kolic J, Marchi P, Sipione S, Macdonald PE (2009) SUMOylation regulates Kv2.1 and modulates pancreatic betacell excitability. J Cell Sci 122:775-779

41. Debonneville C, Flores SY, Kamynina E, Plant PJ, Tauxe C, Thomas MA, Munster C, Chraibi A, Pratt JH, Horisberger JD, Pearce D, Loffing J, Staub O (2001) Phosphorylation of Nedd4-2 by $\mathrm{Sgk} 1$ regulates epithelial $\mathrm{Na}(+)$ channel cell surface expression. EMBO J 20:7052-7059

42. Debonneville C, Staub O (2004) Participation of the ubiquitinconjugating enzyme UBE2E3 in Nedd4-2-dependent regulation of the epithelial Na+ channel. Mol Cell Biol 24:2397-2409

43. Diakov A, Korbmacher C (2004) A novel pathway of epithelial sodium channel activation involves a serum- and glucocorticoidinducible kinase consensus motif in the $\mathrm{C}$ terminus of the channel's alpha-subunit. J Biol Chem 279:38134-38142

44. Dibbens LM, Ekberg J, Taylor I, Hodgson BL, Conroy SJ, Lensink IL, Kumar S, Zielinski MA, Harkin LA, Sutherland GR, Adams DJ, Berkovic SF, Scheffer IE, Mulley JC, Poronnik P (2007) NEDD4-2 as a potential candidate susceptibility gene for epileptic photosensitivity. Genes Brain Behav 6:750-755 
45. Dinudom A, Harvey KF, Komwatana P, Young JA, Kumar S, Cook DI (1998) Nedd4 mediates control of an epithelial $\mathrm{Na}+$ channel in salivary duct cells by cytosolic $\mathrm{Na}+$. Proc Natl Acad Sci USA 95:7169-7173

46. Donaldson SH, Boucher RC (2007) Sodium channels and cystic fibrosis. Chest 132:1631-1636

47. Duc C, Farman N, Canessa CM, Bonvalet JP, Rossier BC (1994) Cell-specific expression of epithelial sodium channel alpha, beta, and gamma subunits in aldosterone-responsive epithelia from the rat: localization by in situ hybridization and immunocytochemistry. J Cell Biol 127:1907-1921

48. Dunn DM, Ishigami T, Pankow J, von Niederhausern A, Alder J, Hunt SC, Leppert MF, Lalouel JM, Weiss RB (2002) Common variant of human NEDD4L activates a cryptic splice site to form a frameshifted transcript. J Hum Genet 47:665-676

49. Edinger RS, Lebowitz J, Li H, Alzamora R, Wang H, Johnson JP, Hallows KR (2009) Functional regulation of the epithelial $\mathrm{Na}+$ channel by IkappaB kinase-beta occurs via phosphorylation of the ubiquitin ligase Nedd4-2. J Biol Chem 284:150-157

50. Ekberg J, Schuetz F, Boase NA, Conroy SJ, Manning J, Kumar S, Poronnik P, Adams DJ (2007) Regulation of the voltage-gated $\mathrm{K}(+)$ channels $\mathrm{KCNQ} 2 / 3$ and $\mathrm{KCNQ} 3 / 5$ by ubiquitination. Novel role for Nedd4-2. J Biol Chem 282:12135-12142

51. Embark HM, Bohmer C, Palmada M, Rajamanickam J, Wyatt AW, Wallisch S, Capasso G, Waldegger P, Seyberth HW, Waldegger S, Lang F (2004) Regulation of CLC-Ka/barttin by the ubiquitin ligase Nedd4-2 and the serum- and glucocorticoiddependent kinases. Kidney Int 66:1918-1925

52. Escayg A, MacDonald BT, Meisler MH, Baulac S, Huberfeld G, An-Gourfinkel I, Brice A, LeGuern E, Moulard B, Chaigne D, Buresi C, Malafosse A (2000) Mutations of SCN1A, encoding a neuronal sodium channel, in two families with GEFS +2 . Nat Genet 24:343-345

53. Estevez R, Boettger T, Stein V, Birkenhager R, Otto E, Hildebrandt F, Jentsch TJ (2001) Barttin is a Cl- channel betasubunit crucial for renal $\mathrm{Cl}$ - reabsorption and inner ear $\mathrm{K}+$ secretion. Nature 414:558-561

54. Fakitsas P, Adam G, Daidie D, van Bemmelen MX, Fouladkou F, Patrignani A, Wagner U, Warth R, Camargo SM, Staub O, Verrey F (2007) Early aldosterone-induced gene product regulates the epithelial sodium channel by deubiquitylation. J Am Soc Nephrol 18:1084-1092

55. Fejes-Toth G, Frindt G, Naray-Fejes-Toth A, Palmer LG (2008) Epithelial $\mathrm{Na}+$ channel activation and processing in mice lacking SGK1. Am J Physiol Ren Physiol 294:F1298-F1305

56. Feliciangeli S, Bendahhou S, Sandoz G, Gounon P, Reichold M, Warth R, Lazdunski M, Barhanin J, Lesage F (2007) Does sumoylation control K2P1/TWIK1 background K + channels? Cell 130:563-569

57. Firsov D, Schild L, Gautschi I, Merillat AM, Schneeberger E, Rossier BC (1996) Cell surface expression of the epithelial $\mathrm{Na}$ channel and a mutant causing Liddle syndrome: a quantitative approach. Proc Natl Acad Sci USA 93:15370-15375

58. Flores SY, Loffing-Cueni D, Kamynina E, Daidie D, Gerbex C, Chabanel S, Dudler J, Loffing J, Staub O (2005) Aldosteroneinduced serum and glucocorticoid-induced kinase 1 expression is accompanied by Nedd4-2 phosphorylation and increased $\mathrm{Na}+$ transport in cortical collecting duct cells. J Am Soc Nephrol $16: 2279-2287$

59. Foot NJ, Dalton HE, Shearwin-Whyatt LM, Dorstyn L, Tan SS, Yang B, Kumar S (2008) Regulation of the divalent metal ion transporter DMT1 and iron homeostasis by a ubiquitindependent mechanism involving Ndfips and WWP2. Blood 112:4268-4275

60. Fotia AB, Dinudom A, Shearwin KE, Koch JP, Korbmacher C, Cook DI, Kumar S (2003) The role of individual Nedd4-2
(KIAA0439) WW domains in binding and regulating epithelial sodium channels. FASEB J 17:70-72

61. Fotia AB, Ekberg J, Adams DJ, Cook DI, Poronnik P, Kumar S (2004) Regulation of neuronal voltage-gated sodium channels by the ubiquitin-protein ligases Nedd4 and Nedd4-2. J Biol Chem 279:28930-28935

62. Fouladkou F, Alikhani-Koopaei R, Vogt B, Flores SY, MalbertColas L, Lecomte MC, Loffing J, Frey FJ, Frey BM, Staub O (2004) A naturally occurring human Nedd4-2 variant displays impaired $\mathrm{ENaC}$ regulation in Xenopus laevis oocytes. Am J Physiol Ren Physiol 287:F550-F561

63. Galan JM, Haguenauer-Tsapis R (1997) Ubiquitin lys63 is involved in ubiquitination of a yeast plasma membrane protein. EMBO J 16:5847-5854

64. Galan JM, Moreau V, Andre B, Volland C, Haguenauer-Tsapis R (1996) Ubiquitination mediated by the Npilp/Rsp5p ubiquitinprotein ligase is required for endocytosis of the yeast uracil permease. J Biol Chem 271:10946-10952

65. Gao Y, Chotoo CK, Balut CM, Sun F, Bailey MA, Devor DC (2008) Role of S3 and S4 transmembrane domain charged amino acids in channel biogenesis and gating of $\mathrm{KCa} 2.3$ and $\mathrm{KCa} 3.1$. J Biol Chem 283:9049-9059

66. Gasser A, Cheng X, Gilmore ES, Tyrrell L, Waxman SG, DibHajj SD (2010) Two Nedd4-binding motifs underlie modulation of sodium channel Nav1.6 by p38 MAPK. J Biol Chem 285:26149-26161

67. Glickman MH, Ciechanover A (2002) The ubiquitin-proteasome proteolytic pathway: destruction for the sake of construction. Physiol Rev 82:373-428

68. Gnann A, Riordan JR, Wolf DH (2004) Cystic fibrosis transmembrane conductance regulator degradation depends on the lectins Htm1p/EDEM and the Cdc48 protein complex in yeast. Mol Biol Cell 15:4125-4135

69. Goldfarb SB, Kashlan OB, Watkins JN, Suaud L, Yan W, Kleyman TR, Rubenstein RC (2006) Differential effects of Hsc70 and Hsp70 on the intracellular trafficking and functional expression of epithelial sodium channels. Proc Natl Acad Sci USA 103:5817-5822

70. Goldstein SA, Wang KW, Ilan N, Pausch MH (1998) Sequence and function of the two $\mathrm{P}$ domain potassium channels: implications of an emerging superfamily. J Mol Med 76:13-20

71. Gorrie GH, Vallis Y, Stephenson A, Whitfield J, Browning B, Smart TG, Moss SJ (1997) Assembly of GABAA receptors composed of alpha1 and beta 2 subunits in both cultured neurons and fibroblasts. J Neurosci 17:6587-6596

72. Gunther W, Piwon N, Jentsch TJ (2003) The ClC-5 chloride channel knock-out mouse - an animal model for Dent's disease. Pflugers Arch 445:456-462

73. Gupta R, Kus B, Fladd C, Wasmuth J, Tonikian R, Sidhu S, Krogan NJ, Parkinson J, Rotin D (2007) Ubiquitination screen using protein microarrays for comprehensive identification of Rsp5 substrates in yeast. Mol Syst Biol 3:116

74. Hansson JH, Nelson-Williams C, Suzuki H, Schild L, Shimkets R, Lu Y, Canessa C, Iwasaki T, Rossier B, Lifton RP (1995) Hypertension caused by a truncated epithelial sodium channel gamma subunit: genetic heterogeneity of Liddle syndrome. Nat Genet 11:76-82

75. Hansson JH, Schild L, Lu Y, Wilson TA, Gautschi I, Shimkets R, Nelson-Williams C, Rossier BC, Lifton RP (1995) A de novo missense mutation of the beta subunit of the epithelial sodium channel causes hypertension and Liddle syndrome, identifying a proline-rich segment critical for regulation of channel activity. Proc Natl Acad Sci USA 92:11495-11499

76. Harvey KF, Dinudom A, Cook DI, Kumar S (2001) The Nedd4like protein KIAA0439 is a potential regulator of the epithelial sodium channel. J Biol Chem 276:8597-8601 
77. He Y, Hryciw DH, Carroll ML, Myers SA, Whitbread AK, Kumar S, Poronnik P, Hooper JD (2008) The ubiquitin-protein ligase Nedd4-2 differentially interacts with and regulates members of the Tweety family of chloride ion channels. J Biol Chem 283:24000-24010

78. Hein C, Springael JY, Volland C, Haguenauer-Tsapis R, Andre B (1995) NP11, an essential yeast gene involved in induced degradation of Gap1 and Fur4 permeases, encodes the Rsp5 ubiquitin-protein ligase. Mol Microbiol 18:77-87

79. Henke G, Maier G, Wallisch S, Boehmer C, Lang F (2004) Regulation of the voltage gated $\mathrm{K}+$ channel Kv1.3 by the ubiquitin ligase Nedd4-2 and the serum and glucocorticoid inducible kinase SGK1. J Cell Physiol 199:194-199

80. Henry PC, Kanelis V, O'Brien MC, Kim B, Gautschi I, FormanKay J, Schild L, Rotin D (2003) Affinity and specificity of interactions between Nedd4 isoforms and the epithelial $\mathrm{Na}+$ channel. J Biol Chem 278:20019-20028

81. Hicke L, Dunn R (2003) Regulation of membrane protein transport by ubiquitin and ubiquitin-binding proteins. Annu Rev Cell Dev Biol 19:141-172

82. Hicke L, Riezman H (1996) Ubiquitination of a yeast plasma membrane receptor signals its ligand-stimulated endocytosis. Cell 84:277-287

83. Howitt J, Putz U, Lackovic J, Doan A, Dorstyn L, Cheng H, Yang B, Chan-Ling T, Silke J, Kumar S, Tan SS (2009) Divalent metal transporter 1 (DMT1) regulation by Ndfip1 prevents metal toxicity in human neurons. Proc Natl Acad Sci USA 106:15489-15494

84. Hryciw DH, Ekberg J, Lee A, Lensink IL, Kumar S, Guggino WB, Cook DI, Pollock CA, Poronnik P (2004) Nedd4-2 functionally interacts with $\mathrm{ClC}-5$ : involvement in constitutive albumin endocytosis in proximal tubule cells. J Biol Chem 279:54996-55007

85. Hu J, Wittekind SG, Barr MM (2007) STAM and Hrs downregulate ciliary TRP receptors. Mol Biol Cell 18:3277-3289

86. Hughey RP, Bruns JB, Kinlough CL, Harkleroad KL, Tong Q, Carattino MD, Johnson JP, Stockand JD, Kleyman TR (2004) Epithelial sodium channels are activated by furin-dependent proteolysis. J Biol Chem 279:18111-18114

87. Hughey RP, Bruns JB, Kinlough CL, Kleyman TR (2004) Distinct pools of epithelial sodium channels are expressed at the plasma membrane. J Biol Chem 279:48491-48494

88. Hughey RP, Carattino MD, Kleyman TR (2007) Role of proteolysis in the activation of epithelial sodium channels. Curr Opin Nephrol Hypertens 16:444-450

89. Hummler E, Vallon V (2005) Lessons from mouse mutants of epithelial sodium channel and its regulatory proteins. J Am Soc Nephrol 16:3160-3166

90. Ichimura T, Yamamura H, Sasamoto K, Tominaga Y, Taoka M, Kakiuchi K, Shinkawa T, Takahashi N, Shimada S, Isobe T (2005) 14-3-3 proteins modulate the expression of epithelial $\mathrm{Na}+$ channels by phosphorylation-dependent interaction with Nedd42 ubiquitin ligase. J Biol Chem 280:13187-13194

91. Igarashi P, Somlo S (2002) Genetics and pathogenesis of polycystic kidney disease. J Am Soc Nephrol 13:2384-2398

92. Itani OA, Campbell JR, Herrero J, Snyder PM, Thomas CP (2003) Alternate promoters and variable splicing lead to hNedd4-2 isoforms with a $\mathrm{C} 2$ domain and varying number of WW domains. Am J Physiol Ren Physiol 285:F916-F929

93. Jensen TJ, Loo MA, Pind S, Williams DB, Goldberg AL, Riordan JR (1995) Multiple proteolytic systems, including the proteasome, contribute to CFTR processing. Cell 83:129-135

94. Jentsch TJ (2008) CLC chloride channels and transporters: from genes to protein structure, pathology and physiology. Crit Rev Biochem Mol Biol 43:3-36

95. Jespersen T, Membrez M, Nicolas CS, Pitard B, Staub O, Olesen SP, Baro I, Abriel H (2007) The KCNQ1 potassium channel is down-regulated by ubiquitylating enzymes of the Nedd4/Nedd4like family. Cardiovasc Res 74:64-74

96. Joch M, Ase AR, Chen CX, MacDonald PA, Kontogiannea M, Corera AT, Brice A, Seguela P, Fon EA (2007) Parkin-mediated monoubiquitination of the PDZ protein PICK1 regulates the activity of acid-sensing ion channels. Mol Biol Cell 18:31053118

97. Kabra R, Knight KK, Zhou R, Snyder PM (2008) Nedd4-2 induces endocytosis and degradation of proteolytically cleaved epithelial Na+ channels. J Biol Chem 283:6033-6039

98. Kamsteeg EJ, Hendriks G, Boone M, Konings IB, Oorschot V, van der Sluijs P, Klumperman J, Deen PM (2006) Short-chain ubiquitination mediates the regulated endocytosis of the aquaporin-2 water channel. Proc Natl Acad Sci USA 103:18344-18349

99. Kamynina E, Debonneville C, Bens M, Vandewalle A, Staub O (2001) A novel mouse Nedd4 protein suppresses the activity of the epithelial Na+ channel. FASEB J 15:204-214

100. Kamynina E, Tauxe C, Staub O (2001) Distinct characteristics of two human Nedd4 proteins with respect to epithelial $\mathrm{Na}(+)$ channel regulation. Am J Physiol Ren Physiol 281:F469-F477

101. Kanelis V, Bruce MC, Skrynnikov NR, Rotin D, Forman-Kay JD (2006) Structural determinants for high-affinity binding in a Nedd4 WW3* domain-Comm PY motif complex. Structure 14:543-553

102. Kanelis V, Rotin D, Forman-Kay JD (2001) Solution structure of a Nedd4 WW domain-ENaC peptide complex. Nat Struct Biol 8:407-412

103. Kashlan OB, Mueller GM, Qamar MZ, Poland PA, Ahner A, Rubenstein RC, Hughey RP, Brodsky JL, Kleyman TR (2007) Small heat shock protein alphaA-crystallin regulates epithelial sodium channel expression. J Biol Chem 282:28149-28156

104. Kato A, Rouach N, Nicoll RA, Bredt DS (2005) Activitydependent NMDA receptor degradation mediated by retrotranslocation and ubiquitination. Proc Natl Acad Sci USA 102:56005605

105. Keating MT, Sanguinetti MC (2001) Molecular and cellular mechanisms of cardiac arrhythmias. Cell 104:569-580

106. Kellenberger S, Gautschi I, Rossier BC, Schild L (1998) Mutations causing Liddle syndrome reduce sodium-dependent downregulation of the epithelial sodium channel in the Xenopus oocyte expression system. J Clin Invest 101:2741-2750

107. Kikkert M, Doolman R, Dai M, Avner R, Hassink G, van Voorden S, Thanedar S, Roitelman J, Chau V, Wiertz E (2004) Human HRD1 is an E3 ubiquitin ligase involved in degradation of proteins from the endoplasmic reticulum. J Biol Chem 279:3525-3534

108. Knight KK, Olson DR, Zhou R, Snyder PM (2006) Liddle's syndrome mutations increase $\mathrm{Na}+$ transport through dual effects on epithelial $\mathrm{Na}+$ channel surface expression and proteolytic cleavage. Proc Natl Acad Sci USA 103:2805-2808

109. Kopito RR (1999) Biosynthesis and degradation of CFTR. Physiol Rev 79:S167-S173

110. Kruse M, Schulze-Bahr E, Corfield V, Beckmann A, Stallmeyer B, Kurtbay G, Ohmert I, Brink P, Pongs O (2009) Impaired endocytosis of the ion channel TRPM4 is associated with human progressive familial heart block type I. J Clin Invest 119:27372744

111. Lauwers E, Jacob C, Andre B (2009) K63-linked ubiquitin chains as a specific signal for protein sorting into the multivesicular body pathway. J Cell Biol 185:493-502

112. Lee IH, Dinudom A, Sanchez-Perez A, Kumar S, Cook DI (2007) Akt mediates the effect of insulin on epithelial sodium channels by inhibiting Nedd4-2. J Biol Chem 282:29866-29873

113. Lesage F, Guillemare E, Fink M, Duprat F, Lazdunski M, Romey G, Barhanin J (1996) TWIK-1, a ubiquitous human weakly 
inward rectifying $\mathrm{K}+$ channel with a novel structure. EMBO J 15:1004-1011

114. Levkowitz G, Klapper LN, Tzahar E, Freywald A, Sela M, Yarden Y (1996) Coupling of the c-Cbl protooncogene product to ErbB-1/EGF-receptor but not to other ErbB proteins. Oncogene 12:1117-1125

115. Leykauf K, Salek M, Bomke J, Frech M, Lehmann WD, Durst M, Alonso A (2006) Ubiquitin protein ligase Nedd4 binds to connexin 43 by a phosphorylation-modulated process. J Cell Sci 119:3634-3642

116. Li T, Koshy S, Folkesson HG (2007) Involvement of \{alpha\} $\mathrm{ENaC}$ and Nedd4-2 in the conversion from lung fluid secretion to fluid absorption at birth in the rat as assayed by RNA interference analysis. Am J Physiol Lung Cell Mol Physiol 293: L1069-L1078

117. Li T, Koshy S, Folkesson HG (2009) IL-1beta-induced cortisol stimulates lung fluid absorption in fetal guinea pigs via SGKmediated Nedd4-2 inhibition. Am J Physiol Lung Cell Mol Physiol 296:L527-L533

118. Liang X, Butterworth MB, Peters KW, Walker WH, Frizzell RA (2008) An obligatory heterodimer of 14-3-3beta and 14-33epsilon is required for aldosterone regulation of the epithelial sodium channel. J Biol Chem 283:27418-27425

119. Liang X, Peters KW, Butterworth MB, Frizzell RA (2006) 14-33 isoforms are induced by aldosterone and participate in its regulation of epithelial sodium channels. J Biol Chem 281:16323-16332

120. Lifton RP, Gharavi AG, Geller DS (2001) Molecular mechanisms of human hypertension. Cell 104:545-556

121. Lilley BN, Ploegh HL (2005) Multiprotein complexes that link dislocation, ubiquitination, and extraction of misfolded proteins from the endoplasmic reticulum membrane. Proc Natl Acad Sci USA 102:14296-14301

122. Lin CH, MacGurn JA, Chu T, Stefan CJ, Emr SD (2008) Arrestin-related ubiquitin-ligase adaptors regulate endocytosis and protein turnover at the cell surface. Cell 135:714-725

123. Lin DH, Yue P, Pan CY, Sun P, Zhang X, Han Z, Roos M, Caplan M, Giebisch G, Wang WH (2009) POSH stimulates the ubiquitination and the clathrin-independent endocytosis of ROMK1 channels. J Biol Chem 284:29614-29624

124. Liu XF, Supek F, Nelson N, Culotta VC (1997) Negative control of heavy metal uptake by the Saccharomyces cerevisiae BSD2 gene. J Biol Chem 272:11763-11769

125. Loffing J, Korbmacher C (2009) Regulated sodium transport in the renal connecting tubule (CNT) via the epithelial sodium channel (ENaC). Pflugers Arch 458:111-135

126. Loffing J, Zecevic M, Feraille E, Kaissling B, Asher C, Rossier BC, Firestone GL, Pearce D, Verrey F (2001) Aldosterone induces rapid apical translocation of $\mathrm{ENaC}$ in early portion of renal collecting system: possible role of SGK. Am J Physiol Ren Physiol 280:F675-F682

127. Lu C, Pribanic S, Debonneville A, Jiang C, Rotin D (2007) The PY motif of $\mathrm{ENaC}$, mutated in Liddle syndrome, regulates channel internalization, sorting and mobilization from subapical pool. Traffic 8:1246-1264

128. Luo F, Wang Y, Wang X, Sun K, Zhou X, Hui R (2009) A functional variant of NEDD4L is associated with hypertension, antihypertensive response, and orthostatic hypotension. Hypertension 54:796-801

129. Malik B, Schlanger L, Al-Khalili O, Bao HF, Yue G, Price SR, Mitch WE, Eaton DC (2001) Enac degradation in A6 cells by the ubiquitin-proteosome proteolytic pathway. J Biol Chem 276:12903-12910

130. Malik B, Yue Q, Yue G, Chen XJ, Price SR, Mitch WE, Eaton DC (2005) Role of Nedd4-2 and polyubiquitination in epithelial sodium channel degradation in untransfected renal A6 cells expressing endogenous ENaC subunits. Am J Physiol Ren Physiol 289:F107-F116

131. Mall M, Grubb BR, Harkema JR, O'Neal WK, Boucher RC (2004) Increased airway epithelial $\mathrm{Na}+$ absorption produces cystic fibrosis-like lung disease in mice. Nat Med 10:487-493

132. Manganas LN, Akhtar S, Antonucci DE, Campomanes CR, Dolly JO, Trimmer JS (2001) Episodic ataxia type-1 mutations in the Kv1.1 potassium channel display distinct folding and intracellular trafficking properties. J Biol Chem 276:4942749434

133. Manganas LN, Wang Q, Scannevin RH, Antonucci DE, Rhodes KJ, Trimmer JS (2001) Identification of a trafficking determinant localized to the Kv1 potassium channel pore. Proc Natl Acad Sci USA 98:14055-14059

134. May A, Puoti A, Gaeggeler HP, Horisberger JD, Rossier BC (1997) Early effect of aldosterone on the rate of synthesis of the epithelial sodium channel alpha subunit in A6 renal cells. J Am Soc Nephrol 8:1813-1822

135. McDonald FJ, Price MP, Snyder PM, Welsh MJ (1995) Cloning and expression of the beta- and gamma-subunits of the human epithelial sodium channel. Am J Physiol 268:C1157-C1163

136. McNicholas CM, Canessa CM (1997) Diversity of channels generated by different combinations of epithelial sodium channel subunits. J Gen Physiol 109:681-692

137. Meacham GC, Patterson C, Zhang W, Younger JM, Cyr DM (2001) The Hsc70 co-chaperone CHIP targets immature CFTR for proteasomal degradation. Nat Cell Biol 3:100-105

138. Michlig S, Harris M, Loffing J, Rossier BC, Firsov D (2005) Progesterone down-regulates the open probability of the amiloride-sensitive epithelial sodium channel via a Nedd4-2dependent mechanism. J Biol Chem 280:38264-38270

139. Morito D, Hirao K, Oda Y, Hosokawa N, Tokunaga F, Cyr DM, Tanaka K, Iwai K, Nagata K (2008) Gp78 cooperates with RMA1 in endoplasmic reticulum-associated degradation of CFTRDeltaF508. Mol Biol Cell 19:1328-1336

140. Mueller B, Lilley BN, Ploegh HL (2006) SEL1L, the homologue of yeast $\mathrm{Hrd} 3 \mathrm{p}$, is involved in protein dislocation from the mammalian ER. J Cell Biol 175:261-270

141. Nakatsukasa K, Brodsky JL (2008) The recognition and retrotranslocation of misfolded proteins from the endoplasmic reticulum. Traffic 9:861-870

142. Naray-Fejes-Toth A, Canessa C, Cleaveland ES, Aldrich G, Fejes-Toth G (1999) sgk is an aldosterone-induced kinase in the renal collecting duct. Effects on epithelial nat channels. J Biol Chem 274:16973-16978

143. Nishikawa SI, Fewell SW, Kato Y, Brodsky JL, Endo T (2001) Molecular chaperones in the yeast endoplasmic reticulum maintain the solubility of proteins for retrotranslocation and degradation. J Cell Biol 153:1061-1070

144. O'Kelly I, Butler MH, Zilberberg N, Goldstein SA (2002) Forward transport. 14-3-3 binding overcomes retention in endoplasmic reticulum by dibasic signals. Cell 111:577-588

145. Oda Y, Okada T, Yoshida H, Kaufman RJ, Nagata K, Mori K (2006) Derlin-2 and Derlin-3 are regulated by the mammalian unfolded protein response and are required for ER-associated degradation. J Cell Biol 172:383-393

146. Okiyoneda T, Barriere H, Bagdany M, Rabeh WM, Du K, Hohfeld J, Young JC, Lukacs GL (2010) Peripheral protein quality control removes unfolded CFTR from the plasma membrane. Science 329:805-810

147. Okiyoneda T, Harada K, Takeya M, Yamahira K, Wada I, Shuto T, Suico MA, Hashimoto Y, Kai H (2004) Delta F508 CFTR pool in the endoplasmic reticulum is increased by calnexin overexpression. Mol Biol Cell 15:563-574

148. Orias M, Velazquez H, Tung F, Lee G, Desir GV (1997) Cloning and localization of a double-pore $\mathrm{K}$ channel, KCNK1: exclusive 
expression in distal nephron segments. Am J Physiol 273:F663F666

149. Paiva S, Vieira N, Nondier I, Haguenauer-Tsapis R, Casal M, Urban-Grimal D (2009) Glucose-induced ubiquitylation and endocytosis of the yeast Jen1 transporter: role of lysine 63linked ubiquitin chains. J Biol Chem 284:19228-19236

150. Palmada M, Dieter M, Boehmer C, Waldegger S, Lang F (2004) Serum and glucocorticoid inducible kinases functionally regulate ClC-2 channels. Biochem Biophys Res Commun 321:1001-1006

151. Palmer LG, Sackin H, Frindt G (1998) Regulation of $\mathrm{Na}+$ channels by luminal $\mathrm{Na}+$ in rat cortical collecting tubule. J Physiol 509(Pt 1):151-162

152. Papadatos GA, Wallerstein PM, Head CE, Ratcliff R, Brady PA, Benndorf K, Saumarez RC, Trezise AE, Huang CL, Vandenberg JI, Colledge WH, Grace AA (2002) Slowed conduction and ventricular tachycardia after targeted disruption of the cardiac sodium channel gene Scn5a. Proc Natl Acad Sci USA 99:6210-6215

153. Passero CJ, Mueller GM, Rondon-Berrios H, Tofovic SP, Hughey RP, Kleyman TR (2008) Plasmin activates epithelial $\mathrm{Na}+$ channels by cleaving the gamma subunit. J Biol Chem 283:36586-36591

154. Pearce MM, Wang Y, Kelley GG, Wojcikiewicz RJ (2007) SPFH2 mediates the endoplasmic reticulum-associated degradation of inositol 1, 4, 5-trisphosphate receptors and other substrates in mammalian cells. J Biol Chem 282:20104-20115

155. Persaud A, Alberts P, Amsen EM, Xiong X, Wasmuth J, Saadon Z, Fladd C, Parkinson J, Rotin D (2009) Comparison of substrate specificity of the ubiquitin ligases Nedd4 and Nedd4-2 using proteome arrays. Mol Syst Biol 5:333

156. Piwon N, Gunther W, Schwake M, Bosl MR, Jentsch TJ (2000) $\mathrm{ClC}-5 \mathrm{Cl}-$-channel disruption impairs endocytosis in a mouse model for Dent's disease. Nature 408:369-373

157. Plant LD, Dementieva IS, Kollewe A, Olikara S, Marks JD, Goldstein SA (2010) One SUMO is sufficient to silence the dimeric potassium channel K2P1. Proc Natl Acad Sci USA 107:10743-10748

158. Pourrier M, Schram G, Nattel S (2003) Properties, expression and potential roles of cardiac $\mathrm{K}+$ channel accessory subunits: MinK, MiRPs, KChIP, and KChAP. J Membr Biol 194:141-152

159. Pradervand S, Wang Q, Burnier M, Beermann F, Horisberger JD, Hummler E, Rossier BC (1999) A mouse model for Liddle's syndrome. J Am Soc Nephrol 10:2527-2533

160. Rabinovich E, Kerem A, Frohlich KU, Diamant N, Bar-Nun S (2002) AAA-ATPase p97/Cdc48p, a cytosolic chaperone required for endoplasmic reticulum-associated protein degradation. Mol Cell Biol 22:626-634

161. Rajan S, Plant LD, Rabin ML, Butler MH, Goldstein SA (2005) Sumoylation silences the plasma membrane leak $\mathrm{K}+$ channel K2P1. Cell 121:37-47

162. Randrianarison N, Escoubet B, Ferreira C, Fontayne A, FowlerJaeger N, Clerici C, Hummler E, Rossier BC, Planes C (2007) beta-Liddle mutation of the epithelial sodium channel increases alveolar fluid clearance and reduces the severity of hydrostatic pulmonary oedema in mice. J Physiol 582:777-788

163. Rauh R, Dinudom A, Fotia AB, Paulides M, Kumar S, Korbmacher C, Cook DI (2006) Stimulation of the epithelial sodium channel $(\mathrm{ENaC})$ by the serum- and glucocorticoidinducible kinase (Sgk) involves the PY motifs of the channel but is independent of sodium feedback inhibition. Pflugers Arch 452:290-299

164. Reid CA, Berkovic SF, Petrou S (2009) Mechanisms of human inherited epilepsies. Prog Neurobiol 87:41-57

165. Ring AM, Cheng SX, Leng Q, Kahle KT, Rinehart J, Lalioti MD, Volkman HM, Wilson FH, Hebert SC, Lifton RP (2007) WNK4 regulates activity of the epithelial $\mathrm{Na}+$ channel in vitro and in vivo. Proc Natl Acad Sci USA 104:4020-4024
166. Ring AM, Leng Q, Rinehart J, Wilson FH, Kahle KT, Hebert SC, Lifton RP (2007) An SGK1 site in WNK4 regulates $\mathrm{Na}+$ channel and $\mathrm{K}+$ channel activity and has implications for aldosterone signaling and $\mathrm{K}+$ homeostasis. Proc Natl Acad Sci USA 104:4025-4029

167. Riordan JR (2005) Assembly of functional CFTR chloride channels. Annu Rev Physiol 67:701-718

168. Rossier BC, Schild L (2008) Epithelial sodium channel: mendelian versus essential hypertension. Hypertension 52:595-600

169. Rossier BC, Stutts MJ (2009) Activation of the epithelial sodium channel (ENaC) by serine proteases. Annu Rev Physiol 71:361379

170. Rougier JS, van Bemmelen MX, Bruce MC, Jespersen T, Gavillet B, Apotheloz F, Cordonier S, Staub O, Rotin D, Abriel $\mathrm{H}$ (2005) Molecular determinants of voltage-gated sodium channel regulation by the Nedd4/Nedd4-like proteins. Am J Physiol Cell Physiol 288:C692-C701

171. Ruffieux-Daidie D, Poirot O, Boulkroun S, Verrey F, Kellenberger S, Staub O (2008) Deubiquitylation regulates activation and proteolytic cleavage of ENaC. J Am Soc Nephrol 19:21702180

172. Sander T, Schulz H, Saar K, Gennaro E, Riggio MC, Bianchi A, Zara F, Luna D, Bulteau C, Kaminska A, Ville D, Cieuta C, Picard F, Prud'homme JF, Bate L, Sundquist A, Gardiner RM, Janssen GA, de Haan GJ, Kasteleijn-Nolst-Trenite DG, Bader A, Lindhout D, Riess O, Wienker TF, Janz D, Reis A (2000) Genome search for susceptibility loci of common idiopathic generalised epilepsies. Hum Mol Genet 9:1465-1472

173. Schild L, Lu Y, Gautschi I, Schneeberger E, Lifton RP, Rossier BC (1996) Identification of a PY motif in the epithelial $\mathrm{Na}$ channel subunits as a target sequence for mutations causing channel activation found in Liddle syndrome. EMBO J 15:23812387

174. Schmidt JW, Catterall WA (1986) Biosynthesis and processing of the alpha subunit of the voltage-sensitive sodium channel in rat brain neurons. Cell 46:437-444

175. Schuetz F, Kumar S, Poronnik P, Adams DJ (2008) Regulation of the voltage-gated $\mathrm{K}(+)$ channels $\mathrm{KCNQ} 2 / 3$ and $\mathrm{KCNQ} 3 / 5$ by serum- and glucocorticoid-regulated kinase-1. Am J Physiol Cell Physiol 295:C73-C80

176. Schwake M, Friedrich T, Jentsch TJ (2001) An internalization signal in $\mathrm{ClC}-5$, an endosomal Cl-channel mutated in dent's disease. J Biol Chem 276:12049-12054

177. Schwartz AL, Ciechanover A (2008) Targeting proteins for destruction by the ubiquitin system: implications for human pathobiology. Annu Rev Pharmacol Toxicol 49:73-96

178. Sheng S, Carattino MD, Bruns JB, Hughey RP, Kleyman TR (2006) Furin cleavage activates the epithelial $\mathrm{Na}+$ channel by relieving $\mathrm{Na}+$ self-inhibition. Am J Physiol Ren Physiol 290: F1488-F1496

179. Shi G, Nakahira K, Hammond S, Rhodes KJ, Schechter LE, Trimmer JS (1996) Beta subunits promote K+ channel surface expression through effects early in biosynthesis. Neuron 16:843852

180. Shi H, Asher C, Chigaev A, Yung Y, Reuveny E, Seger R, Garty $\mathrm{H}$ (2002) Interactions of beta and gamma $\mathrm{ENaC}$ with Nedd4 can be facilitated by an ERK-mediated phosphorylation. J Biol Chem 277:13539-13547

181. Shi PP, Cao XR, Sweezer EM, Kinney TS, Williams NR, Husted RF, Nair R, Weiss RM, Williamson RA, Sigmund CD, Snyder PM, Staub O, Stokes JB, Yang B (2008) Salt-sensitive hypertension and cardiac hypertrophy in mice deficient in the ubiquitin ligase Nedd42. Am J Physiol Ren Physiol 295:F462-F470

182. Shigaev A, Asher C, Latter H, Garty H, Reuveny E (2000) Regulation of sgk by aldosterone and its effects on the epithelial $\mathrm{Na}(+)$ channel. Am J Physiol Ren Physiol 278:F613-F619 
183. Shimkets RA, Warnock DG, Bositis CM, Nelson-Williams C, Hansson JH, Schambelan M, Gill JR Jr, Ulick S, Milora RV, Findling JW et al (1994) Liddle's syndrome: heritable human hypertension caused by mutations in the beta subunit of the epithelial sodium channel. Cell 79:407-414

184. Snyder PM, Olson DR, Kabra R, Zhou R, Steines JC (2004) cAMP and serum and glucocorticoid-inducible kinase (SGK) regulate the epithelial $\mathrm{Na}(+)$ channel through convergent phosphorylation of Nedd4-2. J Biol Chem 279:45753-45758

185. Snyder PM, Olson DR, McDonald FJ, Bucher DB (2001) Multiple WW domains, but not the $\mathrm{C} 2$ domain, are required for inhibition of the epithelial $\mathrm{Na}+$ channel by human Nedd4. J Biol Chem 276:28321-28326

186. Snyder PM, Olson DR, Thomas BC (2002) Serum and glucocorticoid-regulated kinase modulates Nedd4-2-mediated inhibition of the epithelial Na+ channel. J Biol Chem 277:5-8

187. Snyder PM, Price MP, McDonald FJ, Adams CM, Volk KA, Zeiher BG, Stokes JB, Welsh MJ (1995) Mechanism by which Liddle's syndrome mutations increase activity of a human epithelial Na+ channel. Cell 83:969-978

188. Snyder PM, Steines JC, Olson DR (2004) Relative contribution of Nedd4 and Nedd4-2 to ENaC regulation in epithelia determined by RNA interference. J Biol Chem 279:5042-5046

189. Soetens O, De Craene JO, Andre B (2001) Ubiquitin is required for sorting to the vacuole of the yeast general amino acid permease, Gap1. J Biol Chem 276:43949-43957

190. Standley S, Roche KW, McCallum J, Sans N, Wenthold RJ (2000) PDZ domain suppression of an ER retention signal in NMDA receptor NR1 splice variants. Neuron 28:887-898

191. Staub O, Dho S, Henry P, Correa J, Ishikawa T, McGlade J, Rotin D (1996) WW domains of Nedd4 bind to the proline-rich PY motifs in the epithelial $\mathrm{Na}+$ channel deleted in Liddle's syndrome. EMBO J 15:2371-2380

192. Staub O, Gautschi I, Ishikawa T, Breitschopf K, Ciechanover A, Schild L, Rotin D (1997) Regulation of stability and function of the epithelial $\mathrm{Na}+$ channel $(\mathrm{ENaC})$ by ubiquitination. EMBO J 16:6325-6336

193. Stokes A, Wakano C, Koblan-Huberson M, Adra CN, Fleig A, Turner H (2006) TRPA1 is a substrate for de-ubiquitination by the tumor suppressor CYLD. Cell Signal 18:1584-1594

194. Stutts MJ, Rossier BC, Boucher RC (1997) Cystic fibrosis transmembrane conductance regulator inverts protein kinase Amediated regulation of epithelial sodium channel single channel kinetics. J Biol Chem 272:14037-14040

195. Suzuki M, Mizuno A (2004) A novel human Cl(-) channel family related to Drosophila flightless locus. J Biol Chem 279:22461-22468

196. Swanson R, Locher M, Hochstrasser M (2001) A conserved ubiquitin ligase of the nuclear envelope/endoplasmic reticulum that functions in both ER-associated and Matalpha2 repressor degradation. Genes Dev 15:2660-2674

197. Thomas MA, Zosso N, Scerri I, Demaurex N, Chanson M, Staub O (2003) A tyrosine-based sorting signal is involved in connexin43 stability and gap junction turnover. J Cell Sci 116:2213-2222

198. Tian Y, Kolb R, Hong JH, Carroll J, Li D, You J, Bronson R, Yaffe MB, Zhou J, Benjamin T (2007) TAZ promotes PC2 degradation through a SCFbeta-Trcp E3 ligase complex. Mol Cell Biol 27:6383-6395

199. Tiffany AM, Manganas LN, Kim E, Hsueh YP, Sheng M, Trimmer JS (2000) PSD-95 and SAP97 exhibit distinct mechanisms for regulating $\mathrm{K}(+)$ channel surface expression and clustering. J Cell Biol 148:147-158

200. Uchida S, Marumo F (2000) Severely impaired urineconcentrating ability in mice lacking the CLC-K1 chloride channel. Exp Nephrol 8:361-365
201. Ushioda R, Hoseki J, Araki K, Jansen G, Thomas DY, Nagata K (2008) ERdj5 is required as a disulfide reductase for degradation of misfolded proteins in the ER. Science 321:569-572

202. Valentijn JA, Fyfe GK, Canessa CM (1998) Biosynthesis and processing of epithelial sodium channels in Xenopus oocytes. $\mathrm{J}$ Biol Chem 273:30344-30351

203. Vallet V, Chraibi A, Gaeggeler HP, Horisberger JD, Rossier BC (1997) An epithelial serine protease activates the amiloridesensitive sodium channel. Nature 389:607-610

204. van Bemmelen MX, Rougier JS, Gavillet B, Apotheloz F, Daidie D, Tateyama M, Rivolta I, Thomas MA, Kass RS, Staub O, Abriel H (2004) Cardiac voltage-gated sodium channel Nav1.5 is regulated by Nedd4-2 mediated ubiquitination. Circ Res 95:284 291

205. VanSlyke JK, Deschenes SM, Musil LS (2000) Intracellular transport, assembly, and degradation of wild-type and diseaselinked mutant gap junction proteins. Mol Biol Cell 11:19331946

206. Vashist S, Ng DT (2004) Misfolded proteins are sorted by a sequential checkpoint mechanism of ER quality control. J Cell Biol 165:41-52

207. Wanamaker CP, Christianson JC, Green WN (2003) Regulation of nicotinic acetylcholine receptor assembly. Ann NY Acad Sci 998:66-80

208. Wang J, Peng Q, Lin Q, Childress C, Carey D, Yang W (2010) Calcium activates Nedd4 E3 ubiquitin ligases by releasing the C2 domain-mediated auto-inhibition. J Biol Chem 285:1227912288

209. Wang Y, Fu X, Gaiser S, Kottgen M, Kramer-Zucker A, Walz G, Wegierski T (2007) OS-9 regulates the transit and polyubiquitination of TRPV4 in the endoplasmic reticulum. J Biol Chem 282:36561-36570

210. Ward CL, Omura S, Kopito RR (1995) Degradation of CFTR by the ubiquitin-proteasome pathway. Cell 83:121-127

211. Webster JM, Tiwari S, Weissman AM, Wojcikiewicz RJ (2003) Inositol 1, 4, 5-trisphosphate receptor ubiquitination is mediated by mammalian Ubc7, a component of the endoplasmic reticulum-associated degradation pathway, and is inhibited by chelation of intracellular Zn2+. J Biol Chem 278:38238-38246

212. Webster MK, Goya L, Ge Y, Maiyar AC, Firestone GL (1993) Characterization of sgk, a novel member of the serine/threonine protein kinase gene family which is transcriptionally induced by glucocorticoids and serum. Mol Cell Biol 13:2031-2040

213. Wegierski T, Hill K, Schaefer M, Walz G (2006) The HECT ubiquitin ligase AIP4 regulates the cell surface expression of select TRP channels. EMBO J 25:5659-5669

214. Weisz OA, Wang JM, Edinger RS, Johnson JP (2000) Noncoordinate regulation of endogenous epithelial sodium channel $(\mathrm{ENaC})$ subunit expression at the apical membrane of A6 cells in response to various transporting conditions. J Biol Chem 275:39886-39893

215. Wellhauser L, D'Antonio C, Bear CE (2010) ClC transporters: discoveries and challenges in defining the mechanisms underlying function and regulation of ClC-5. Pflugers Arch 460:543 $-557$

216. Wiemuth D, Ke Y, Rohlfs M, McDonald FJ (2007) Epithelial sodium channel $(\mathrm{ENaC})$ is multi-ubiquitinated at the cell surface. Biochem J 405:147-155

217. Wiesner S, Ogunjimi AA, Wang HR, Rotin D, Sicheri F, Wrana JL, Forman-Kay JD (2007) Autoinhibition of the HECT-type ubiquitin ligase Smurf2 through its C2 domain. Cell 130:651662

218. Winget JM, Mayor T The diversity of ubiquitin recognition: hot spots and varied specificity. Mol Cell 38:627-635

219. Wojcikiewicz RJ, Xu Q, Webster JM, Alzayady K, Gao C (2003) Ubiquitination and proteasomal degradation of endogenous and 
exogenous inositol 1, 4, 5-trisphosphate receptors in alpha T3-1 anterior pituitary cells. J Biol Chem 278:940-947

220. Wrong OM, Norden AG, Feest TG (1994) Dent's disease; a familial proximal renal tubular syndrome with low-molecularweight proteinuria, hypercalciuria, nephrocalcinosis, metabolic bone disease, progressive renal failure and a marked male predominance. QJM 87:473-493

221. Wulff P, Vallon V, Huang DY, Volkl H, Yu F, Richter K, Jansen M, Schlunz M, Klingel K, Loffing J, Kauselmann G, Bosl MR, Lang F, Kuhl D (2002) Impaired renal $\mathrm{Na}(+)$ retention in the sgk1-knockout mouse. J Clin Invest 110:1263-1268

222. Xu BE, Stippec S, Chu PY, Lazrak A, Li XJ, Lee BH, English JM, Ortega B, Huang CL, Cobb MH (2005) WNK1 activates SGK1 to regulate the epithelial sodium channel. Proc Natl Acad Sci USA 102:10315-10320

223. Xu P, Duong DM, Seyfried NT, Cheng D, Xie Y, Robert J, Rush J, Hochstrasser M, Finley D, Peng J (2009) Quantitative proteomics reveals the function of unconventional ubiquitin chains in proteasomal degradation. Cell 137:133-145

224. Yang JW, Vacher H, Park KS, Clark E, Trimmer JS (2007) Trafficking-dependent phosphorylation of Kv1.2 regulates voltage-gated potassium channel cell surface expression. Proc Natl Acad Sci USA 104:20055-20060

225. Yang LM, Rinke R, Korbmacher C (2006) Stimulation of the epithelial sodium channel $(\mathrm{ENaC})$ by cAMP involves putative ERK phosphorylation sites in the C termini of the channel's betaand gamma-subunit. J Biol Chem 281:9859-9868

226. Yang M, Omura S, Bonifacino JS, Weissman AM (1998) Novel aspects of degradation of $\mathrm{T}$ cell receptor subunits from the endoplasmic reticulum (ER) in T cells: importance of oligosaccharide processing, ubiquitination, and proteasome-dependent removal from ER membranes. J Exp Med 187:835-846
227. Ye Y, Meyer HH, Rapoport TA (2003) Function of the p97Ufd1-Npl4 complex in retrotranslocation from the ER to the cytosol: dual recognition of nonubiquitinated polypeptide segments and polyubiquitin chains. J Cell Biol 162:71-84

228. Ye Y, Shibata Y, Yun C, Ron D, Rapoport TA (2004) A membrane protein complex mediates retro-translocation from the ER lumen into the cytosol. Nature 429:841-847

229. Yoshida Y, Chiba T, Tokunaga F, Kawasaki H, Iwai K, Suzuki T, Ito Y, Matsuoka K, Yoshida M, Tanaka K, Tai T (2002) E3 ubiquitin ligase that recognizes sugar chains. Nature 418:438442

230. Yu FH, Catterall WA (2003) Overview of the voltage-gated sodium channel family. Genome Biol 4:207

231. Zerangue N, Schwappach B, Jan YN, Jan LY (1999) A new ER trafficking signal regulates the subunit stoichiometry of plasma membrane K(ATP) channels. Neuron 22:537-548

232. Zhang $\mathrm{W}, \mathrm{Na}$ T, Wu G, Jing H, Peng JB (2010) Downregulation of intestinal apical calcium entry channel TRPV6 by ubiquitin E3 ligase NEDD4-2. J Biol Chem (in press)

233. Zhang Y, Nijbroek G, Sullivan ML, McCracken AA, Watkins SC, Michaelis S, Brodsky JL (2001) Hsp70 molecular chaperone facilitates endoplasmic reticulum-associated protein degradation of cystic fibrosis transmembrane conductance regulator in yeast. Mol Biol Cell 12:1303-1314

234. Zhou R, Patel SV, Snyder PM (2007) Nedd4-2 catalyzes ubiquitination and degradation of cell surface ENaC. J Biol Chem 282:20207-20212

235. Zhou Z, Treis D, Schubert SC, Harm M, Schatterny J, Hirtz S, Duerr J, Boucher RC, Mall MA (2008) Preventive but not late amiloride therapy reduces morbidity and mortality of lung disease in betaENaC-overexpressing mice. Am J Respir Crit Care Med 178:1245-1256 